\title{
Preeclampsia: Risk Factors, Diagnosis, Management, and the Cardiovascular Impact on the Offspring
}

\author{
Rachael Fox ${ }^{1,2}$, Jamie Kitt ${ }^{1}$, Paul Leeson ${ }^{1}$, Christina Y.L. Aye ${ }^{1,3}$ and Adam J. Lewandowski ${ }^{1, *}$ \\ 1 Oxford Cardiovascular Clinical Research Facility, Division of Cardiovascular Medicine, Radcliffe \\ Department of Medicine, University of Oxford, Oxford OX3 9DU, UK; foxr@student.unimelb.edu.au (R.F.); \\ jamie.kitt@cardiov.ox.ac.uk (J.K.); paul.leeson@cardiov.ox.ac.uk (P.L.); \\ christina.aye@googlemail.com (C.Y.L.A.) \\ 2 University of Melbourne, Victoria 3010, Australia \\ 3 Nuffield Department of Women's and Reproductive Health, University of Oxford, Oxford OX3 9DU, UK \\ * Correspondence: adam.lewandowski@cardiov.ox.ac.uk; Tel.: +44-(0)-186-522-3680; Fax: +44-(0)-186-557-2840
}

Received: 8 September 2019; Accepted: 2 October 2019; Published: 4 October 2019

\begin{abstract}
Hypertensive disorders of pregnancy affect up to $10 \%$ of pregnancies worldwide, which includes the $3 \%-5 \%$ of all pregnancies complicated by preeclampsia. Preeclampsia is defined as new onset hypertension after 20 weeks' gestation with evidence of maternal organ or uteroplacental dysfunction or proteinuria. Despite its prevalence, the risk factors that have been identified lack accuracy in predicting its onset and preventative therapies only moderately reduce a woman's risk of preeclampsia. Preeclampsia is a major cause of maternal morbidity and is associated with adverse foetal outcomes including intra-uterine growth restriction, preterm birth, placental abruption, foetal distress, and foetal death in utero. At present, national guidelines for foetal surveillance in preeclamptic pregnancies are inconsistent, due to a lack of evidence detailing the most appropriate assessment modalities as well as the timing and frequency at which assessments should be conducted. Current management of the foetus in preeclampsia involves timely delivery and prevention of adverse effects of prematurity with antenatal corticosteroids and/or magnesium sulphate depending on gestation. Alongside the risks to the foetus during pregnancy, there is also growing evidence that preeclampsia has long-term adverse effects on the offspring. In particular, preeclampsia has been associated with cardiovascular sequelae in the offspring including hypertension and altered vascular function.
\end{abstract}

Keywords: foetus; preeclampsia; pregnancy; foetal diseases; prevention; treatment; developmental origins of disease; non-communicable disease

\section{Introduction}

Hypertensive disorders of pregnancy affect $10 \%$ of pregnancies [1] and are defined by the International Society for the Study of Hypertension in Pregnancy (ISSHP) as new onset hypertension ( $\geq 140 \mathrm{mmHg}$ systolic or $\geq 90 \mathrm{mmHg}$ diastolic) after 20 weeks' gestation [2]. This umbrella definition includes chronic hypertension, gestational hypertension and preeclampsia (de novo or superimposed on chronic hypertension). Both of these conditions can have significant impacts on maternal and foetal health in the immediate and long term. For the mother, this includes a two- to four-fold increased risk of long-term hypertension, a doubling of the risk of cardiovascular mortality and major adverse cardiovascular events, and a 1.5-fold increased risk of stroke [3]. For the foetus, this includes antenatal risks of intra-uterine growth restriction (IUGR), preterm birth (most commonly iatrogenic), oligohydramnios, placental abruption, foetal distress, and foetal death in utero [4-6]. There is also growing evidence that in utero exposure to hypertensive disorders of pregnancy can result in 
significant long-term cardiovascular sequelae in the offspring, including early onset hypertension, and an increased risk of ischemic heart disease and stroke [7]. These sequelae have been associated with hypertensive pregnancies independent of other coexisting pregnancy complications. This article reviews the latest evidence base and guideline updates surrounding the diagnosis, management, and foetal surveillance in preeclampsia, as well as its increasingly recognised role as an independent cardiovascular risk factor for the offspring.

\section{Risk Factors for Preeclampsia and Risk Reduction}

The 2019 National Institute for Health and Care Excellence (NICE) guidelines [3] classify a woman at high risk of preeclampsia if there is a history of hypertensive disease during a previous pregnancy or a maternal disease including chronic kidney disease, autoimmune diseases, diabetes, or chronic hypertension. Women are at moderate risk if they are nulliparous, $\geq 40$ years of age, have a body mass index $(\mathrm{BMI}) \geq 35 \mathrm{~kg} / \mathrm{m}$ [2], a family history of preeclampsia, a multifoetal pregnancy, or a pregnancy interval of more than 10 years [3]. These risk factors are echoed in the largest meta-analysis of clinical risk factors to date conducted by Bartsch et al. [8], who analysed over 25 million pregnancies from 92 studies. The presence of one high risk factor, or two or more moderate risk factors, is used to help guide aspirin prophylaxis, which is effective in reducing the risk of preeclampsia if administered before 16 weeks of pregnancy $[9,10]$.

There are additional clinical factors that significantly increase preeclampsia risk, including raised mean arterial blood pressure before 15 weeks' gestation [11], polycystic ovarian syndrome [12-14], sleep disordered breathing [15], and various infections such as periodontal disease, urinary tract infections [16], and helicobacter pylori $[17,18]$. In terms of obstetric history, vaginal bleeding for at least five days during pregnancy increases preeclampsia risk [11], as does the use of oocyte donation, which has a higher risk of preeclampsia in comparison to in vitro fertilization (IVF) without oocyte donation or natural conception [19-21].

Biochemical and ultrasound markers are being investigated as additional predictors for preeclampsia. Foetal factors including genotype and foetal cell-free DNA in maternal blood can influence a woman's risk of preeclampsia $[22,23]$. Recently, a genome-wide association study of 4380 cases of preeclampsia and 310,238 controls identified that a variant in the foetal genome near the locus of fms-like tyrosine kinase-1 (Flt-1) is implicated in the development of preeclampsia [22]. Increased cell-free foetal DNA in maternal blood is another potential marker, and is detectable before onset of symptoms [24]. The most promising foetal and placental biomarkers for identifying preeclampsia are placental growth factor (PlGF) and soluble Flt-1 (sFlt-1), which are discussed subsequently. Meta-analyses have described a potential association between preeclampsia and elevated levels of serum triglycerides, cholesterol, and inflammatory markers including CRP, IL-6, IL-8, and TNF $\alpha$, some of which precede the onset of preeclampsia [25-28]. Uterine artery Doppler analysis has mixed results in predicting preeclampsia $[11,29,30]$. A recent meta-analysis reported that use between 11 and 14 weeks can predict preeclampsia with similar accuracy as clinical risk factors [30]. Incorporation of specialist tests such as uterine artery pulsatility index and pregnancy-associate plasma protein A (PAPP-A) into clinical risk prediction models can also increase the positive predictive value for detecting women at risk of this condition [31].

At present, aspirin is the only therapy with robust evidence supporting its use to reduce the risk of preeclampsia in high-risk women [32]. Current recommendations advise low dose (75-150 mg) aspirin as prophylaxis from 12 weeks' gestation until delivery [3]. When taken before 16 weeks' gestation, low dose aspirin has a modest, but consistent effect, estimated to reduce the risk of preeclampsia by approximately $10 \%$ [9]. Other interventions including nutritional supplements, pharmacological agents, and dietary and lifestyle interventions have been investigated for protective effects against preeclampsia with varying efficacy. Studies have reported that vitamin D deficiency can increase the risk of preeclampsia [33-38], and that vitamin D supplementation may offer some benefit in reducing preeclampsia risk $[38,39]$. However, while supplementation is often recommended in clinical practice, 
robust randomised controlled trial (RCT) evidence is still required to confirm its utility $[37,38,40]$. The World Health Organization conducted a large RCT investigating the role of calcium, reporting no decrease in preeclampsia with supplementation in a calcium-deficient population, although the severity and complications of preeclampsia were significantly lower in the supplementation cohort [41]. A 2018 Cochrane review of high dose ( $>1 \mathrm{~g} /$ day) calcium supplementation from 20 weeks' gestation did see a reduction in preeclampsia, although this finding relied on small studies and is likely an over-estimate [42]. Current guidelines cite this as evidence for calcium supplementation in deficient pregnant women $[43,44]$. Supplementation of the antioxidants vitamins $C$ and $E$ has no benefit in preventing preeclampsia [45-48] despite initial promising results [49]. Likewise, high dose folic acid does not appear to have any preventative effects [50], though some evidence suggests that supplementation with 5-methyl-tetrahydrofolate supplementation, a more bioavailable form of folic acid, may be effective in preventing recurrent preeclampsia [51].

A Cochrane review reported that antithrombotic agents such as low molecular weight heparin reduce preeclampsia risk in women at higher risk of placental insufficiency, but significant heterogeneity between the studies limited the certainty of conclusions [52]. A variety of other pharmaceutical agents have been assessed and in small studies. L-arginine, pravastatin, coenzyme Q10, and ketanserin have all been associated with lower rates of preeclampsia. However, larger studies are needed to evaluate their efficacy and safety [53-56].

Lifestyle interventions may reduce preeclampsia, particularly dietary interventions [57,58]. Lower rates of preeclampsia may be associated with a higher vegetable and plant-based diet [11,59], however, findings are mixed. A recent RCT reported that antenatal lifestyle advice (diet and exercise) had no effect on preeclampsia rates in overweight or obese women [60]. Exercise interventions seem to have a more limited effect than diet [61], although there is insufficient evidence to make consistent conclusions [62]. Surprisingly, smoking has been identified as a protective factor against the development of preeclampsia, with risk inversely proportional to number of cigarettes smoked [63].

\section{Diagnosis}

Internationally, preeclampsia is defined as new-onset gestational hypertension (systolic blood pressure $\geq 140 \mathrm{mmHg}$ and/or diastolic blood pressure $\geq 90 \mathrm{mmHg}$ ) associated with new-onset of at least one of proteinuria, maternal organ dysfunction (liver, neurological, haematological, or renal involvement), or uteroplacental dysfunction at or after 20 weeks' gestation (Table 1) [2]. It is important to note that preeclampsia may develop for the first time intrapartum or postpartum. Super-imposed preeclampsia can also be diagnosed in women with chronic hypertension who develop new onset proteinuria, maternal organ, or uteroplacental dysfunction consistent with preeclampsia [2]. Eclampsia occurs when there are convulsions in the setting of preeclampsia [3].

\subsection{Blood Pressure}

In order to confirm the presence of hypertension, blood pressure should be measured on at least two occasions four hours apart using an appropriately sized cuff and validated device for use in women with preeclampsia [2,64]. For women at high risk, guidelines recommend monitoring blood pressure at increased frequency in antenatal clinics, however no exact frequency is recommended. Recent studies have addressed the potential for women to self-monitor their blood pressure at home to improve the detection of hypertension in pregnancy, particularly in women with elevated risk. It appears that self-monitoring is feasible [65,66], acceptable to pregnant women [67], may reduce clinic visits [66], and be effective for detecting hypertension in pregnancy and distinguishing white coat hypertension [68]. A current RCT (BUMP) hopes to provide a larger evidence base to determine the impact of self-monitoring on maternal and neonatal outcomes and advise how self-monitoring can be implemented into clinical practice (www.phc.ox.ac.uk/research/participate/bump-trial). 
Table 1. Diagnostic criteria for preeclampsia.

\begin{tabular}{|c|c|}
\hline \multicolumn{2}{|c|}{$\begin{array}{c}\text { Preeclampsia is Defined as Gestational Hypertension Associated with New-Onset Maternal or } \\
\text { Uteroplacental Dysfunction at or after } 20 \text { Weeks' Gestation }\end{array}$} \\
\hline \multicolumn{2}{|r|}{ Gestational hypertension } \\
\hline \multicolumn{2}{|c|}{ Systolic blood pressure $\geq 140$ and/or diastolic blood pressure $\geq 90$} \\
\hline \multicolumn{2}{|c|}{ Blood pressure should be repeated to confirm true hypertension } \\
\hline \multicolumn{2}{|c|}{ A liquid crystal sphygmomanometer should be used with appropriate size cuff. } \\
\hline \multicolumn{2}{|c|}{ Or, if unavailable an appropriately calibrated automated device. } \\
\hline \multicolumn{2}{|c|}{ Accompanied by at $\geq 1$ of the following new-onset conditions: } \\
\hline Proteinuria & $\begin{array}{c}\text { Initial assessment with automated dipstick urinalysis. If unavailable, } \\
\text { visual analysis can be used. }\end{array}$ \\
\hline & $\begin{array}{l}\text { If dipstick is positive ( } \geq 1+) \text {, confirmed with spot urine. Abnormal if } \\
\text { P:Cr } \geq 30 \mathrm{mg} / \mathrm{mmol} \text { or } \mathrm{A}: \mathrm{Cr} \geq 8 \mathrm{mg} / \mathrm{mmol}\end{array}$ \\
\hline Renal complications & Acute Kidney Injury (creatinine $\geq 90$ umol/L) \\
\hline Liver complications & $\begin{array}{c}\text { Elevated transaminases, with or without right upper quadrant of } \\
\text { epigastric abdominal pain }\end{array}$ \\
\hline Neurological complications & $\begin{array}{c}\text { Eclampsia, altered mental status, blindness, stroke, clonus, severe and } \\
\text { persistent visual scotomata }\end{array}$ \\
\hline Haematological complications & $\begin{array}{c}\text { Thrombocytopenia (platelet count }<150000 / \mu \mathrm{L}, \text { disseminated } \\
\text { intravascular coagulation, haemolysis) }\end{array}$ \\
\hline Uteroplacental dysfunction & $\begin{array}{c}\text { Foetal growth restriction, abnormal umbilical artery Doppler wave form } \\
\text { analysis, stillbirth }\end{array}$ \\
\hline
\end{tabular}

\subsection{Proteinuria}

The presence of proteinuria has traditionally been screened for by dipstick testing and confirmed by additional laboratory tests using $24 \mathrm{~h}$ urine, or more recently spot samples of urine. Screening assessment with dipstick testing is best done with an automated reagent-strip reading device rather than visual analysis [69]. Previously, $24 \mathrm{~h}$ urine collection was considered the gold standard for confirmation of proteinuria but it has several problems: it is time consuming, requires refrigeration, samples are often incomplete, and is infrequently used in hospitals [70]. Therefore, after a positive dipstick test (one protein or more), the use of either spot urine albumin to creatinine (A:Cr) or protein to creatinine $(\mathrm{P}: \mathrm{Cr}$ ) ratios are now recommended to quantify proteinuria [3]. Both $\mathrm{P}: \mathrm{Cr}$ and $\mathrm{A}: \mathrm{Cr}$ testing are shown to significantly correlate with proteinuria as detected by $24 \mathrm{~h}$ urine [71-75]. Diagnostic thresholds of $30 \mathrm{mg} / \mathrm{mmol}$ and $8 \mathrm{mg} / \mathrm{mmol}$ have been determined to provide high sensitivity and specificity, respectively $[71,73]$.

\subsection{Laboratory and Imaging Tests}

The ISSHP recommends that pregnant women with de novo hypertension are investigated with laboratory tests measuring haemoglobin, platelet count, serum creatinine, liver enzymes, and serum uric acid to determine the presence of maternal organ dysfunction and the diagnosis of preeclampsia [2]. New guidelines have also implemented PIGF or sFlt-1:PIGF ratio testing for preeclampsia diagnosis in specific circumstances [3]. There is a large body of work indicating a role of circulating angiogenic factors, such as sFlt-1 and PlGF, in the pathogenesis of preeclampsia. Women with preeclampsia have higher circulating levels of sFlt-1 and lower levels of PlGF, noticeable before the onset of the disease [76]. SFlt-1 is an anti-angiogenic protein that acts as an antagonist to the angiogenic proteins PlGF and vascular endothelial growth factor (VEGF). By inhibiting VEGF and PlGF, sFlt-1 alters downstream signalling pathways, which results in vasoconstriction and endothelial dysfunction [77]. Increasing sFlt-1 levels in mouse models have been shown to produce a syndrome resembling preeclampsia. Furthermore, removing sFlt-1 can reverse endothelial dysfunction in endothelial cell culture studies; hence overexpression appears an important mechanistic link between placental dysfunction and altered maternal vascular function [76]. Low PIGF has been shown to have a high sensitivity and negative predictive value in diagnosing preeclampsia needing delivery within 14 days [78]. A large 
UK based stepped-wedge cluster-randomised controlled trial showed that those who had revealed PIGF testing received a diagnosis of preeclampsia significantly faster, with a significant reduction in adverse maternal events and no change in neonatal adverse outcomes [79]. Another large trial demonstrated that a sFlt-1:PlGF ratio of $<38$ can rule out preeclampsia within the next seven days [80]. NICE have adopted this research, recommending the use of PIGF or sFlt-1:PIGF ratio to help rule out preeclampsia in women between 20 and $34+6$ weeks' gestation in whom preeclampsia is suspected. It is not currently recommended to rule in preeclampsia [3].

Uteroplacental dysfunction can be evaluated with ultrasound assessment of foetal growth and umbilical artery Doppler velocimetry or cerebroplacental ratio measurements to assess blood flow redistribution in placental insufficiency [3].

\section{Impact on the Foetus}

\subsection{Outcomes}

The pathogenesis of preeclampsia is complex and not fully understood, however it is known to involve dysfunctional placentation, systemic inflammation, and oxidative stress [81] as has been described elsewhere [81-83]. Abnormal placentation occurs due to failure of appropriate remodelling of the spiral arteries, resulting in higher resistance to placental blood flow and hypoperfusion of the placenta. This causes chronic placental ischemia and reduced blood flow to the developing foetus [81]. These maladaptive processes can precipitate foetal hypoxia and adverse outcomes including IUGR, preterm birth (both spontaneous and iatrogenic), oligohydramnios, placental abruption, foetal distress, and foetal death in utero [4-6]. The frequency of foetal complications differs depending on the onset of preeclampsia. Early onset of preeclampsia has been associated with significantly higher rates of adverse outcomes for the foetus, including IUGR, oligohydramnios, and foetal death $[4,5]$.

\subsection{Surveillance and Diagnosis of Complications}

Currently, there is no established consensus regarding the optimal monitoring of the foetus in preeclamptic pregnancies. Guidelines developed by the UK, USA, Canada, Australia, and New Zealand differ significantly in the modalities recommended for foetal surveillance and the frequency of assessment they recommend, as illustrated in Table 2. In general, measures used for foetal surveillance include maternal reports of foetal movements, biophysical profile (BPP), cardiotocography (CTG), amniotic fluid volume (AFV) assessment, ultrasound assessment of foetal growth, as well as ultrasound Doppler measurements of the umbilical artery, ductus venosus, middle cerebral artery, and cerebroplacental ratio.

Table 2. Routine recommendations for foetal surveillance in preeclampsia without severe features.

\begin{tabular}{cccccc}
\hline Guideline & Cardiotocograph & Biophysical Profile & $\begin{array}{c}\text { Amniotic Fluid } \\
\text { Volume }\end{array}$ & $\begin{array}{c}\text { Umbilical Artery } \\
\text { Doppler }\end{array}$ & $\begin{array}{c}\text { Ultrasound for } \\
\text { Foetal Growth }\end{array}$ \\
\hline $\begin{array}{c}\text { NICE (United } \\
\text { Kingdom })^{+}[3]\end{array}$ & $\begin{array}{c}\text { At diagnosis. } \\
\text { If normal, do not } \\
\text { routinely repeat } \\
\text { unless indicated. }\end{array}$ & Not recommended & $\begin{array}{c}\text { At diagnosis and } \\
\text { every two weeks. }\end{array}$ & $\begin{array}{c}\text { At diagnosis and } \\
\text { every two weeks. }\end{array}$ & $\begin{array}{c}\text { At diagnosis and } \\
\text { every two weeks. }\end{array}$ \\
\hline $\begin{array}{c}\text { SOMANZ (Australia } \\
\text { and New Zealand) }\end{array}$ & $\begin{array}{c}\text { Twice weekly or } \\
\text { more frequently if } \\
\text { indicated. }\end{array}$ & Not recommended & $\begin{array}{c}\text { At diagnosis and } \\
\text { every two to } \\
\text { three weeks. }\end{array}$ & $\begin{array}{c}\text { At diagnosis and } \\
\text { every two to } \\
\text { three weeks. }\end{array}$ & $\begin{array}{c}\text { At diagnosis and } \\
\text { every two to } \\
\text { three weeks. }\end{array}$ \\
\hline $\begin{array}{c}\text { ACOG (United States } \\
\text { of America) [44,84] }\end{array}$ & $\begin{array}{c}\text { At diagnosis, then } \\
\text { twice weekly. }\end{array}$ & $\begin{array}{c}\text { If CTG is } \\
\text { non-reactive. }\end{array}$ & $\begin{array}{c}\text { At diagnosis, then at } \\
\text { least once weekly. }\end{array}$ & $\begin{array}{c}\text { Adjunct if there is } \\
\text { evidence of foetal } \\
\text { growth restriction. }\end{array}$ & $\begin{array}{c}\text { At diagnosis and } \\
\text { every three to } \\
\text { four weeks. }\end{array}$ \\
\hline SOGC (Canada) [64] & $\begin{array}{c}\text { Recommended, } \\
\text { however timing not } \\
\text { specified. }\end{array}$ & Not recommended & $\begin{array}{c}\text { Recommended, } \\
\text { however timing not } \\
\text { specified. }\end{array}$ & $\begin{array}{c}\text { Recommended, } \\
\text { however timing not } \\
\text { specified. }\end{array}$ & $\begin{array}{c}\text { Recommended. } \\
\text { Timing not specified. }\end{array}$ \\
\hline
\end{tabular}

NICE, National Institute for Health and Care Excellence; SOMANZ, Society of Obstetric Medicine of Australia and New Zealand; ACOG, The American College of Obstetricians and Gynecologists; and SOGC, Society of Obstetricians and Gynaecologists of Canada. ${ }^{\dagger}$ Subsequent surveillance and monitoring depending on scan findings. * These recommendations are suggested as a commonly used guideline. Individual units are advised to develop their own protocols. 
Pregnant women with preeclampsia are often encouraged to monitor foetal movements and report any changes to a health practitioner [44]. However, as a surveillance technique, daily monitoring of foetal movements does not appear to improve foetal outcomes or to prevent stillbirth [85]. BPP testing, which utilizes antenatal CTG alongside ultrasound assessments of foetal movements, breathing, tone, and amniotic fluid volume, is another method of monitoring foetal wellbeing, and recommended in American guidelines [44]. However, use of BPP is not supported by current evidence in high risk pregnancies, including those complicated by preeclampsia [86]. Australian and US guidelines recommend antenatal CTG to measure foetal heart rate at diagnosis of preeclampsia, and subsequently twice weekly for assessment of foetal wellbeing $[43,44]$. Nevertheless, there is no clear evidence that antenatal CTG monitoring improves perinatal outcomes [87]. As a result, the latest NICE guidelines state to repeat CTG 'when clinically indicated' rather than routinely [3]. Other modalities for foetal assessment include ultrasound measurement of foetal weight, which is used at diagnosis of preeclampsia, and then two to three times weekly with the aim to detect IUGR [3,43]. Assessment of AFV allows the detection of oligohydramnios and is also recommended as part of foetal assessment $[3,43]$. AFV can be assessed with ultrasound measurements of the single deepest vertical pocket or by amniotic fluid index, with similar prevention of perinatal outcomes [88].

Unlike previously mentioned investigations, the use of umbilical artery Doppler ultrasound for foetal surveillance in high risk pregnancies is supported by several RCTs and systematic reviews [89-91]. Doppler ultrasound of the foetal umbilical artery measures blood flow patterns through the artery as an indicator of placental perfusion. If the umbilical artery flow is absent or reversed during end-diastole, this illustrates abnormally high placental resistance, hence reduced foetal blood flow, and is an indicator of risk of adverse foetal outcome including perinatal mortality [92]. Additionally, if a foetus is compromised, Doppler ultrasound changes precede changes in foetal heart rate, allowing earlier detection [93]. The majority of evidence regarding the use of umbilical artery Doppler comes from trials of 'high risk' pregnancies, in which preeclamptic pregnancies are included. However, there are very limited studies addressing the use of umbilical artery Doppler in preeclamptic pregnancies specifically. One of the largest RCTs involving umbilical artery Doppler assessments includes 1340 women with high risk pregnancies randomized into surveillance with CTG testing or umbilical artery Doppler velocimetry [89]. They reported significantly lower rates of caesarean sections for foetal distress in the cohort undergoing Doppler assessments. Notably, this impact was most pronounced in women with high risk pregnancies due to maternal hypertension. The reduction of emergency caesareans was suggested to be a result of earlier detection of foetal distress, allowing enough placental reserve for the foetus to endure labour. An early systematic review of 12 RCTs evaluating the use of umbilical artery Doppler ultrasound in high risk pregnancies reported a $38 \%$ reduction in odds in perinatal death [91]. While this reduction in risk of perinatal death is compelling, it is thought to be overstated. A more recent Cochrane review reported a $29 \%$ reduction in mortality [90]. These mixed results are largely explained by the heterogeneous nature of studies due to differences in study design. This includes different classifications of high risk pregnancies, gestational age at inclusion, institutional procedures, Doppler velocimetry equipment and settings, ultrasound operators, and the number of examinations, which limit the results from meta-analyses [94]. Regardless, re-examination of these RCTs has shown enough evidence to confirm umbilical artery Doppler velocimetry does reduce unnecessary obstetric interventions (such as induction of labour and caesarean sections) and perinatal mortality, particularly in pregnancies complicated by IUGR or preeclampsia, and should be conducted in these cases [94]. There remains a lack of evidence to guide specific recommendations regarding initial timing of surveillance with umbilical artery Doppler ultrasound and the ongoing frequency of its use. The studies analysed in the Cochrane review mentioned above differ in the frequency of Doppler assessments conducted and in the gestational age at which analysis was commenced [90]. Some conducted umbilical artery Doppler assessments multiple times per week, while others at fortnightly intervals. As absence or reversal of end diastolic flow is unlikely to occur within seven to 10 days of a normal umbilical artery Doppler analysis [43], in the absence of abnormal findings, guidelines often 
recommend repeat assessment fortnightly from diagnosis until birth $[3,43]$. Nevertheless, the optimal timing and frequency of umbilical artery Doppler assessment remain elusive.

Additional Doppler ultrasound measurements used in assessment include monitoring of the ductus venosus or the foetal middle cerebral artery (MCA). Changes in flow through the ductus venosus occur in placental compromise and hypoxia [95], and Doppler assessment can be useful in assessing foetal wellbeing in early onset placental dysfunction [96]. Resistance in the cerebral arteries decreases with worsening growth restriction and hypoxemia as a mechanism to prioritize blood flow to the brain [97]. An abnormally low pulsatility index (PI), a marker of vascular impedance, in the MCA has been observed in preeclamptic pregnancies including those complicated by IUGR, particularly in later gestations $[97,98]$. However, on its own the MCA is not necessarily a reliable indicator of poor foetal outcome [98]. Instead, utilizing ratios combining the PI of the MCA with that of the umbilical artery or uterine artery are more useful [98-100]. The MCA to umbilical artery resistance index is known as the cerebroplacental ratio and is a good predictor of adverse neonatal outcome [101,102], with a higher diagnostic accuracy in predicting IUGR than either measurement alone [98]. Measurement of the MCA to uterine artery PI ratio has also shown promising results of identifying unfavourable foetal outcomes [99,100]. With disturbance to placental blood flow, resistance is increased in the uterine artery [103] and, if the pregnancy is associated with growth restriction, resistance is decreased in the MCA [97]. Two studies have demonstrated that in preeclampsia, at or beyond 26 weeks' gestation, a low MCA/uterine artery PI is associated with higher rates of unfavourable foetal outcomes including IUGR, caesarean sections, and preterm birth, and it provides a better prediction of outcome than umbilical artery Doppler $[99,100]$. Though these trials were both small, the findings were consistent and further research may confirm clinical utility.

In addition to surveillance methods currently recommended by national obstetric guidelines, studies have considered other measures to predict adverse foetal outcomes in preeclamptic pregnancies. Biochemical tests normally performed in preeclamptic pregnancies have limited use in predicting foetal complications; the degree of proteinuria and level of serum uric acid are poor predictors $[104,105]$ and the presence of abnormal liver function tests can moderately predict foetal complications, but with poor sensitivity [106]. Preliminary data from small cohorts has found CRP levels and the nitric oxide inhibitor maternal plasma asymmetric dimethylarginine to be associated with foetal growth restriction in preeclamptic pregnancies $[107,108]$, though evidence is not sufficient to suggest clinical use.

At present, due to a lack of evidence regarding foetal surveillance, there is disparity between guidelines. Additionally, the disease trajectory of preeclampsia can be unpredictable and can change rapidly, so the foetal surveillance techniques employed need to be altered appropriately based on the current maternal and foetal condition [43]. As a result, decisions regarding the modality and frequency for foetal assessment often rely on the practicing obstetrician and individual institutional guidelines.

\subsection{Management}

Interventions for the management and prevention of foetal complications of preeclampsia are limited. As preeclampsia is responsible for around $20 \%-30 \%$ of all preterm births [109], the management options available to optimize the condition of the foetus, such as administration of antenatal corticosteroids and magnesium sulphate infusions, are primarily aimed at preventing adverse outcomes associated with prematurity. Additionally, prevention of adverse foetal outcomes involves optimizing the timing of delivery. However, choosing the timing of delivery is not purely an intervention to reduce foetal complications, and requires a careful balance of the condition and gestation of the foetus and the condition of the mother. Managing preeclampsia also involves optimization of the maternal condition with antihypertensives, and magnesium sulphate if required [3], which may also provide benefits to the foetus.

Antenatal corticosteroids are recommended if a woman with preeclampsia is suspected to deliver prematurely (between 26 and 36 weeks' gestation) within the next seven days [110]. A single course of corticosteroids (betamethasone or dexamethasone) is supported by robust evidence to reduce the risk of 
perinatal death and neonatal complications including respiratory distress syndrome (RDS), necrotizing enterocolitis, and intensive care admissions in pregnancies at risk of preterm birth [111]. While studies include women at risk of preterm birth regardless of the cause, subgroup analysis indicates there is no evidence to suggest any difference of effect in preterm birth as a result of hypertensive disease [111]. The optimal corticosteroid to use, mode of administration at which gestations steroids are effective, and whether repeat dosing is beneficial is less clear. A Cochrane review reported that it remains uncertain whether use of dexamethasone or betamethasone is preferred; one trial showed dexamethasone may reduce neonatal intraventricular haemorrhage rates more than betamethasone, though they were equivalent for other neonatal outcomes measured [112]. One small trial suggested intramuscular injection may be a more beneficial mode of delivery than oral, however, more evidence is needed to support this [112]. Though it is known that two doses of the corticosteroid are required, it is unclear whether an interval of 12 or $24 \mathrm{~h}$ between these doses is more effective [113]. In terms of gestation, most evidence for the administration of antenatal corticosteroids to minimize foetal and neonatal complications supports its use between 26 and 34 weeks' gestation [111]. After 34 weeks' gestation, evidence is less robust, with some trials showing no benefit [114]. Nevertheless, a subgroup analysis by gestation in a Cochrane review suggested that despite less evidence, there remains a clear clinical benefit of corticosteroids to reduce RDS after 34 weeks, suggesting any risks are outweighed by potential benefits [111]. Additionally, a meta-analysis has shown that if an elective caesarean is planned, antenatal corticosteroids may still reduce rates of RDS after 37 weeks' gestation [115]. In spite of this, corticosteroids have been shown to cause long-term changes in the vasculature and glucose metabolism of the offspring [116], which needs to be considered on balance with the benefits at later gestations.

Several RCTs have assessed whether multiple courses of antenatal corticosteroids are beneficial if after the initial dose, a woman does not deliver within seven days and is still at risk of preterm birth. Results of three large RCTs are conflicting [117-119]. One trial of 982 women at less than 32 weeks of pregnancy who were at high risk of preterm birth saw them randomized seven or more days after initial corticosteroid treatment to weekly repeat dosing of betamethasone or placebo injections [117]. They reported a reduction in RDS and severe lung disease, but lower offspring weight and head circumferences at birth. These findings are consistent with another RCT of 1348 women between 28 and 35 weeks of pregnancy [119]. In contrast, another large RCT of 1858 women did not find any improvement in birth outcomes with repeat dosing of betamethasone, but also reported a detrimental effect on birth size [118]. All studies used intramuscular betamethasone of a similar dose, but the most noticeable difference in methodology was the frequency of repeat dosing, which was weekly, every ten days, and fortnightly in the three studies respectively. Two of the trials reported follow-up at two years, and one at five years [120-122]. In all of these long-term follow-up studies no differences were noticed in mortality, body weight, or neurodevelopmental disability [120-122]. Due to the lack of certainty in benefit and risks, at present guidelines do not recommend repeat courses of corticosteroids as routine care [110].

Magnesium sulphate is given as primary and secondary prophylaxis of seizures in women with preeclampsia regardless of gestation and is also recommended in planned or expected preterm delivery for its neuroprotective effects in the offspring. NICE recommends infusion within $24 \mathrm{~h}$ in women with preeclampsia between 24 and 30 weeks' gestation, and should be considered in women up to 34 weeks' gestation [3]. Magnesium sulphate appears safe for the foetus and meta-analysis has shown that administration antenatally can reduce the risk of cerebral palsy in the offspring [123]. However, the majority of large trials conducted have excluded women delivering preterm as a consequence of preeclampsia. Data from the largest trial that did include women with preeclampsia did not find any significant difference in neonatal morbidity [124], childhood death, or disability at 18 months in those whose mothers were given magnesium sulphate or placebo [125]. Although, there was a tendency to reduction in death and cerebral palsy with magnesium sulphate, this did not reach statistical significance [125]. Therefore, while magnesium sulphate is recommended for foetal neuroprotection in women with preeclampsia at risk of imminent delivery at less than 34 weeks' gestation, the evidence 
supporting this recommendation largely comes from trials in which preeclampsia was excluded as a cause of preterm birth.

The only definitive treatment for preeclampsia is delivery. Optimal timing of delivery requires a careful balance of maternal and foetal risks, including the gestation of the foetus. Overall, indications for planned early delivery are usually maternal, however foetal complications such as abnormalities in foetal ultrasound or CTG monitoring may also result in the decision for early birth [3]. Adverse outcomes in the offspring, including perinatal mortality, are strongly linked to the gestational age at delivery. In general, from a foetal perspective, at early gestations continuation of the pregnancy is desirable in order to improve prognosis [126] unless there is severe placental dysfunction. Therefore, in the absence of other indications, recommendations regarding expectant or immediate management and the optimal timing of delivery differ depending on the gestational age at which preeclampsia is diagnosed. If the onset of preeclampsia is before 24 weeks' gestation (pre-viable), continuing with the pregnancy may not be advisable, due to high maternal morbidity and mortality rates and a low chance of offspring survival [127]. From 24 to 34 weeks of pregnancy, delivery within $24-48 \mathrm{~h}$ is associated with increased risks of adverse events for the foetus and neonate. These include intraventricular haemorrhage, low birth weight, longer stays in intensive care, and increased requirement for respiratory support [128]. Therefore, in women with preeclampsia before 34 weeks' gestation, delaying delivery if possible is likely to be beneficial for the offspring. Between 34 and 37 weeks' gestation, immediate delivery appears beneficial for the mother, however, it can increase adverse neonatal outcomes such as RDS, especially if at less than 36 weeks' gestation [129]. The decision to deliver the foetus immediately or to continue expectant management at these gestations can be difficult. In general, it is advised to continue expectant management unless there are indications that immediate delivery is required [3,129]. The largest trial to date assessing optimal time for delivery in preeclamptic pregnancies between 34 and 37 weeks' gestation is currently underway and should provide further evidence [130]. After 37 weeks' gestation, expectant management or interventional management does not appear to affect neonatal outcomes, however interventional management is beneficial for the mother and is therefore advised [131].

These recommendations according to gestation may not be applicable in the presence of maternal or foetal complications that require more immediate delivery. Foetal indications for delivery may include severe IUGR or evidence of worsening foetal compromise on surveillance modalities, indicating foetal hypoxia $[3,43,84]$. More specifically, this may include persistent reversed end-diastolic flow in umbilical artery Doppler velocimetry or a nonreassuring CTG, though no consensus exists regarding the most appropriate trigger for delivery $[3,84]$. If foetal compromise is present, delaying delivery may damage brain development due to prolonged foetal hypoxia, yet early delivery carries the risks associated with prematurity. One study designed to assess this randomised 548 pregnant women to early or delayed delivery. Women were between 24 and 36 weeks of pregnancy with signs of foetal compromise and uncertainty about the most appropriate time to deliver. No difference was seen in infant mortality prior to hospital discharge, or in death or disability at two years of age [132,133], leaving the optimal management unclear. In this study, $43 \%$ of the pregnancies were hypertensive, but further evidence is lacking regarding when to deliver in the setting of foetal compromise specifically in preeclamptic pregnancies.

Assessment of the ductus venosus flow may provide a promising method to predict perinatal outcome and appropriately time delivery in preeclamptic pregnancies complicated by IUGR. A prospective cohort study identified that in pregnancies complicated by early onset IUGR, an abnormally high ductus venosus pulsatility index can predict adverse foetal outcome more accurately and earlier than changes in foetal heart rate or by umbilical artery Doppler [134]. It may therefore be a more useful parameter for timing delivery. This has been further assessed in a recent multicentre randomised trial of pregnancies complicated by early onset IUGR, in which $\backsim 50 \%$ were preeclamptic [135]. This study compared neonatal outcomes when three different antenatal monitoring strategies were used in order to time delivery: reduced foetal heart rate on CTG, early ductus venosus changes (as measured by high pulsatility index), or late ductus 
venosus changes (measured by the absence of an A wave). They found that by two years of age, neonates assigned to the cohort in which prediction of delivery was based on late ductus venosus changes had a significant reduction in neurodevelopmental impairment when corrected for prematurity. This suggests that a more conservative approach in timing delivery, by waiting for late ductus venosus changes, may improve perinatal outcomes.

Novel management options studied to reduce adverse foetal outcomes of preeclampsia include antithrombin, sildenafil, pravastatin, metformin, and plasma exchange. Antithrombin has been shown in a small trial to preserve foetal biophysical profile and weight gain in early onset preeclampsia (<32 weeks) [136]. Most evidence regarding sildenafil comes from studies on preeclamptic rat models in which foetal blood flow and outcomes have been improved with its use [137]. There has also been a small preliminary trial of sildenafil in women with severe IUGR, which has shown an improved foetal growth velocity and a trend towards improved perinatal survival. In animal models, pravastatin has been demonstrated to reduce IUGR, lower blood pressure, and improve the balance of angiogenic factors by promoting release of PIGF and suppressing sFlt-1 and soluble endoglin production [138]. Similarly, pravastatin administration in human umbilical vein endothelial cells (HUVECs), cytotrophoblasts, and placental tissue results in reduced markers of endothelial dysfunction [139]. Despite concerns of teratogenicity, pravastatin use in small studies has not been associated with adverse pregnancy outcomes including birth defects $[138,140]$ and further studies are currently underway to validate use as a potential treatment. (StAmP trial: Statins to Ameliorate Early Onset Preeclampsia (ISRCTN23410175)). Metformin has also emerged as a potential treatment option for preeclampsia. In preclinical studies using primary human tissue, metformin reduced sflt- 1 and endoglin secretion, improved features of endothelial dysfunction and angiogenesis, and enhanced vasodilation [141]. Due to use in diabetes, metformin is known to be safe in pregnancy, though RCTs evaluating potential use as a treatment for preeclampsia are lacking. Plasma apheresis to facilitate removal of antiangiogenic protein sFlt-1 has also been evaluated as a treatment method. Small pilot studies of apheresis in women with very preterm preeclampsia have shown a reduction in circulating sFlt-1 without apparent adverse maternal or foetal events, and a potential prolongation of pregnancy, warranting larger trials to confirm its utility $[142,143]$. These options do not have sufficient evidence for their use in clinical practice. As such, clinicians rely on monitoring and timely delivery, with the consideration of antenatal corticosteroids and/or magnesium sulphate depending on gestation, as options for improving foetal and neonatal outcomes in preeclampsia.

\section{Long-Term Impact on the Offspring}

There is growing evidence that there are long-term cardiovascular sequelae in the mother following hypertensive pregnancies [144-146] and in the offspring (Figure 1) from in utero exposure to hypertensive disorders of pregnancy, which are independent from other coexisting pregnancy complications. Meta-analysis using data from over 45,000 individuals reported a $2.39 \mathrm{mmHg}$ higher systolic, and $1.35 \mathrm{mmHg}$ higher diastolic blood pressure, in children and young adults born to preeclamptic pregnancies [7]. If this difference tracked into adult life, it would be associated with an $8 \%$ increased risk of mortality from ischemic heart disease and a $12 \%$ increased risk of stroke [7].

These findings are supported by a 20 year prospective follow-up birth cohort study of 2868 young adults, which reported that the clinical incidence of hypertension is increased in those exposed to hypertensive disorders of pregnancy in utero. These young adults were 2.5 times more likely to have global lifetime risk (QRISK) scores above the 75th centile, and 30\% of 20-year-olds with high blood pressure were born following a hypertensive pregnancy [147]. These increases in blood pressure have been shown to track into later life, with one study showing that offspring of preeclamptic pregnancies were more likely to be prescribed antihypertensive medication by 50 years of age [148]. Indeed, a 60 year follow-up of the Helsinki birth cohort also demonstrated that individuals born following severe preeclampsia have a 1.5 relative risk of hypertension [149]. 


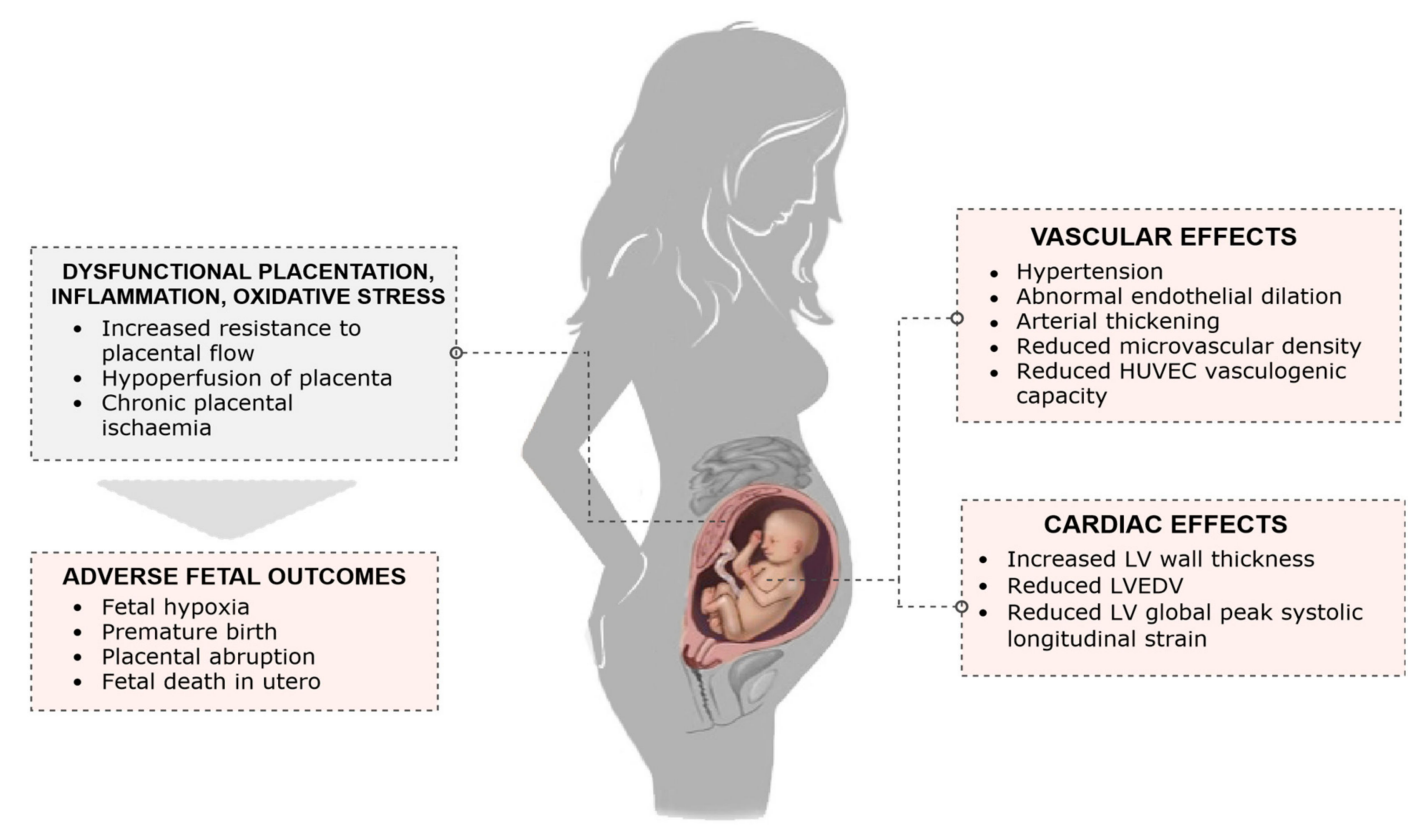

Figure 1. Effects of preeclampsia on the foetus and offspring. HUVEC stands for human umbilical vein endothelial cells; LV, left ventricle; LVEDV, left ventricular end-diastolic volume.

The timing of onset of preeclampsia also appears to be an important determinant in the development of later-life hypertension for the offspring. In one study comparing offspring born to normotensive pregnancies, early onset ( $<34$ weeks' gestation), and late onset ( $\geq 34$ weeks' gestation) preeclamptic pregnancies, blood pressure differences were seen exclusively in the offspring of early onset preeclamptic pregnancies at six and 13 years of age [150]. Those born from mothers with early onset preeclampsia were found to have a $6 \mathrm{mmHg}$ increase in peripheral and central systolic blood pressure, a noticeably greater increase than in studies without discrimination between early or late onset disease [7]. As earlier onset preeclampsia also commonly occurs with IUGR and prematurity, it can be difficult to separate the effects of these on the development of later hypertension. Nevertheless, individuals born preterm to preeclamptic pregnancies have been shown to exhibit specific vascular differences [151]. Moreover, recent research involving 15,000 young adults has described that the siblings of offspring born from preeclamptic pregnancies are also at higher risk of hypertension later in life, even if the mother was not hypertensive in that pregnancy [152]. This suggests that the traditional explanation of in utero stress and developmental reprogramming may not be sufficient to explain the risk of hypertension in those born to a mother with preeclampsia, and suggests a need to explore genetic and epigenetic factors, as well as maternal cardiovascular remodelling, to explain differences in the cardiovascular phenotypes of the offspring [153].

There is a growing body of evidence to suggest that the offspring of preeclamptic pregnancies have a distinct vascular phenotype, which may mediate the increased risk of hypertension [154]. Alterations in vascular function, including abnormal endothelial dilation, and changes in vascular structure, such as arterial thickening, have been found in animal models and human studies on offspring of preeclamptic pregnancies [154]. Lazdam et al. demonstrated that preterm-born young adults have impaired flow mediated endothelial responses only if they were exposed to a hypertensive pregnancy [151]. An increased carotid intima-media thickness was also found in these individuals [151], suggesting an early atherogenic phenotype consistent with aortic arterial thickening. A similar phenotype has also been shown in preeclamptic offspring at birth [155]. Endothelial dysfunction has also been demonstrated in childhood [156] and adolescence [157], although the results are not consistent across studies [158] and further research is needed to better understand between population heterogeneity.

While the precise mechanisms are yet to be fully elucidated, potential mediators for the abnormalities in vascular development in the offspring of preeclamptic pregnancies include derangement of 
maternal angiogenic factors, inherited polymorphisms, epigenetic factors, and altered microRNA expression $[154,159,160]$. Yu et al. [159] analysed the maternal angiogenic profile alongside assessments of neonatal endothelial cells at birth, and vascular density in the offspring at three months postpartum in hypertensive and normotensive pregnancies. At birth, HUVECs from the offspring of hypertensive pregnancies exhibited a lower vasculogenic capacity compared to those of normotensive pregnancies. This correlated with the in vivo microvascular findings in which the offspring born to hypertensive pregnancies exhibited an approximately two-fold reduction in microvascular density in the early postnatal period. This disruption of microvascular development was proportional to peripartum levels of maternal sFlt-1, implicating a role for maternal angiogenic factors in the abnormal development of the foetal vasculature in hypertensive pregnancies [159]. The neonatal microRNA profile also appears to play a role in mediating endothelial changes in the offspring of hypertensive pregnancies [160]. In particular, a specific microRNA involved in endothelial gene regulation, miR-146a, was shown to differ significantly between offspring of normotensive and hypertensive pregnancies, with direct correlations to HUVEC proliferation capacity and tube formation. This elevation in miR-146a expression in HUVECs from hypertensive pregnancies at birth identified cells with reduced ability for in vitro vascular tube formation, which was rescued by miR-146a inhibition. In contrast, miR-146a overexpression significantly reduced vascular tube formation in HUVECs from normotensive pregnancies.

In addition to these vascular changes, a recent study has also discovered differences in the cardiac structure in adolescent offspring exposed to hypertensive disorders of pregnancy, with evidence of adverse cardiac remodelling [161]. Exposure to maternal hypertension was associated with a greater left ventricular wall thickness compared to controls, while those exposed to preeclampsia also demonstrated a reduced left ventricular end-diastolic volume. Similarly, in a study by Lewandowski et al. in preterm-born young adults, preterm offspring of hypertensive pregnancies were shown to have an additional reduction in left ventricular global peak systolic longitudinal strain compared to preterm-born young adults born to normotensive pregnancies [162]. Whether these changes are present earlier in life and whether they are of relevance to future cardiovascular disease risk in these populations will be of interest. Alterations in cardiac autonomic function in the offspring, another predictor of cardiac sequalae, as well as the greatest cardiac remodelling changes in early postnatal life, appear to be associated with prematurity but not hypertensive pregnancies per se [163,164].

\section{Conclusions}

Hypertensive disorders of pregnancy now affect around one in 10 pregnancies worldwide [1]. This incidence is continuing to increase worldwide and will continue to do so not only in westernized countries as mothers conceive increasingly later in life, but also in continents where the vast majority of our population now resides. This includes India, Asia, Africa, and South America, where changes in socioeconomic status are resulting in a shift towards conception at an older age, coupled to increasing obesity rates worldwide. In the face of this, advances in screening, detection, and diagnosis as well as the antenatal, perinatal, and postnatal management of preeclampsia are required for the mother and their offspring.

For women at high risk, home blood pressure self-monitoring to improve the detection of hypertension in pregnancy may be warranted. This could be particularly effective in areas of the world where access to regular antenatal clinics and midwives remains is limited. Telemonitored blood pressure offers further potential for earlier diagnosis in remote areas, which is currently being trialled as part of the CRADLE programs $[165,166]$. At present, aspirin is the only therapy with robust evidence to reduce the risk of preeclampsia in high-risk women [32]. Current recommendations advise low dose (75-150 mg) aspirin as prophylaxis from 12 weeks' gestation until delivery [3]. Other interventions including nutritional supplements, pharmacological agents, and dietary and lifestyle interventions have been investigated for protective effects against preeclampsia with varying efficacy [33-62]. At present, interventions to reduce the risk of early foetal complications of preeclampsia remain limited and include administration of antenatal corticosteroids and magnesium sulphate infusions, which are 
primarily aimed at preventing adverse outcomes associated with prematurity. Further research in this field is needed to better understand the potential maternal and offspring benefits of dietary, lifestyle, and home-monitoring interventions for the pre- and postdelivery management of preeclampsia.

Author Contributions: Conceptualization, A.J.L.; Writing-Original Draft Outline, R.F., J.K., C.Y.L.A., A.J.L; Writing-Original Draft Preparation, R.F.; Writing—Review \& Editing, R.F., J.K., C.Y.L.A., P.L, A.J.L.; Supervision, A.J.L.

Funding: The authors acknowledge support from the Oxford British Heart Foundation (BHF) Centre of Research Excellence and National Institute for Health Research (NIHR) Oxford Biomedical Research Centre. Dr Adam Lewandowski is funded by a BHF Intermediate Research Fellowship (FS/18/3/33292).

Conflicts of Interest: The authors declare no conflict of interest. The funders had no role in the design of the study; in the collection, analyses, or interpretation of data; in the writing of the manuscript, or in the decision to publish the results.

\section{References}

1. Ananth, C.V.; Keyes, K.M.; Wapner, R.J. Pre-Eclampsia Rates in the United States, 1980-2010: Age-Period-Cohort Analysis. BMJ 2013, 347, f6564. [CrossRef] [PubMed]

2. Brown, M.A.; Magee, L.A.; Kenny, L.C.; Karumanchi, S.A.; McCarthy, F.P.; Saito, S.; Hall, D.R.; Warren, C.E.; Adoyi, G.; Ishaku, S. Hypertensive Disorders of Pregnancy: ISSHP Classification, Diagnosis, and Management Recommendations for International Practice. Hypertension 2018, 72, 24-43. [CrossRef]

3. National Guideline Alliance (UK). Hypertension in Pregnancy: Diagnosis and Management (NG133). 2019. Available online: https://www.nice.org.uk/guidance/ng133 (accessed on 3 October 2019).

4. Madazli, R.; Yuksel, M.A.; Imamoglu, M.; Tuten, A.; Oncul, M.; Aydin, B.; Demirayak, G. Comparison of Clinical and Perinatal Outcomes in Early- and Late-Onset Preeclampsia. Arch. Gynecol. Obstet. 2014, 290, 53-57. [CrossRef]

5. Haddad, B.; Deis, S.; Goffinet, F.; Paniel, B.J.; Cabrol, D.; Sibaï, B.M. Maternal and Perinatal Outcomes during Expectant Management of 239 Severe Preeclamptic Women between 24 and 33 Weeks' Gestation. Am. J. Obstet. Gynecol. 2004, 190, 1590-1595. [CrossRef] [PubMed]

6. Rezk, M.; Gamal, A.; Emara, M. Maternal and Fetal Outcome in de Novo Preeclampsia in Comparison to Superimposed Preeclampsia: A Two-Year Observational Study. Hypertens. Pregnancy 2015, 34, 137-144. [CrossRef] [PubMed]

7. Davis, E.F.; Lazdam, M.; Lewandowski, A.J.; Worton, S.A.; Kelly, B.; Kenworthy, Y.; Adwani, S.; Wilkinson, A.R.; McCormick, K.; Sargent, I.; et al. Cardiovascular Risk Factors in Children and Young Adults Born to Preeclamptic Pregnancies: A Systematic Review. Pediatrics 2012, 129, e1552-e1561. [CrossRef] [PubMed]

8. Bartsch, E.; Medcalf, K.E.; Park, A.L.; Ray, J.G.; High Risk of Pre-eclampsia Identification Group. Clinical Risk Factors for Pre-Eclampsia Determined in Early Pregnancy: Systematic Review and Meta-Analysis of Large Cohort Studies. BMJ 2016, 353, i1753. [CrossRef] [PubMed]

9. Askie, L.M.; Duley, L.; Henderson-Smart, D.J.; Stewart, L.A. Antiplatelet Agents for Prevention of Pre-Eclampsia: A Meta-Analysis of Individual Patient Data. Lancet 2007, 369, 1791-1798. [CrossRef]

10. Bujold, E.; Roberge, S.; Lacasse, Y.; Bureau, M.; Audibert, F.; Marcoux, S.; Forest, J.C.; Giguère, Y. Prevention of Preeclampsia and Intrauterine Growth Restriction with Aspirin Started in Early Pregnancy: A Meta-Analysis. Obstet. Gynecol. 2010, 116, 402-414. [CrossRef] [PubMed]

11. North, R.A.; McCowan, L.M.E.; Dekker, G.A.; Poston, L.; Chan, E.H.Y.; Stewart, A.W.; Black, M.A.; Taylor, R.S.; Walker, J.J.; Baker, P.N.; et al. Clinical Risk Prediction for Pre-Eclampsia in Nulliparous Women: Development of Model in International Prospective Cohort. BMJ 2011, 342, d1875. [CrossRef] [PubMed]

12. Bahri Khomami, M.; Joham, A.E.; Boyle, J.A.; Piltonen, T.; Silagy, M.; Arora, C.; Misso, M.L.; Teede, H.J.; Moran, L.J. Increased Maternal Pregnancy Complications in Polycystic Ovary Syndrome Appear to Be Independent of Obesity-A Systematic Review, Meta-Analysis, and Meta-Regression. Obes. Rev. 2019, 20, 659-674. [CrossRef] [PubMed]

13. Yu, H.-F.; Chen, H.-S.; Rao, D.-P.; Gong, J. Association between Polycystic Ovary Syndrome and the Risk of Pregnancy Complications: A PRISMA-Compliant Systematic Review and Meta-Analysis. Medicine (Baltimore) 2016, 95, e4863. [CrossRef] [PubMed] 
14. Qin, J.Z.; Pang, L.H.; Li, M.J.; Fan, X.J.; Huang, R.D.; Chen, H.Y. Obstetric Complications in Women with Polycystic Ovary Syndrome: A Systematic Review and Meta-Analysis. Reprod. Biol. Endocrinol. 2013, 11, 56. [CrossRef] [PubMed]

15. Pamidi, S.; Pinto, L.M.; Marc, I.; Benedetti, A.; Schwartzman, K.; Kimoff, R.J. Maternal Sleep-Disordered Breathing and Adverse Pregnancy Outcomes: A Systematic Review and Metaanalysis. Am. J. Obstet. Gynecol. 2014, 210, 52. [CrossRef]

16. Rustveld, L.O.; Kelsey, S.F.; Sharma, R. Association between Maternal Infections and Preeclampsia: A Systematic Review of Epidemiologic Studies. Matern. Child Health J. 2008, 12, 223-242. [CrossRef]

17. Bellos, I.; Daskalakis, G.; Pergialiotis, V. Helicobacter Pylori Infection Increases the Risk of Developing Preeclampsia: A Meta-Analysis of Observational Studies. Int. J. Clin. Pract. 2018, 72, 349-353. [CrossRef]

18. Nourollahpour Shiadeh, M.; Riahi, S.M.; Adam, I.; Saber, V.; Behboodi Moghadam, Z.; Armon, B.; Spotin, A.; Nazari Kangavari, H.; Rostami, A. Helicobacter Pylori Infection and Risk of Preeclampsia: A Systematic Review and Meta-Analysis. J. Matern. Fetal. Neonatal Med. 2019, 32, 324-331. [CrossRef]

19. Blazquez, A.; Garcia, D.; Rodriguez, A.; Vassena, R.; Figueras, F.; Vernaeve, V. Is Oocyte Donation a Risk Factor for Preeclampsia? A Systematic Review and Meta-Analysis. J. Assist. Reprod. Genet. 2016, 33, 855-863. [CrossRef]

20. Jeve, Y.B.; Potdar, N.; Opoku, A.; Khare, M. Donor Oocyte Conception and Pregnancy Complications: A Systematic Review and Meta-Analysis. BJOG 2016, 123, 1471-1480. [CrossRef]

21. Masoudian, P.; Nasr, A.; de Nanassy, J.; Fung-Kee-Fung, K.; Bainbridge, S.A.; El Demellawy, D. Oocyte Donation Pregnancies and the Risk of Preeclampsia or Gestational Hypertension: A Systematic Review and Metaanalysis. Am. J. Obstet. Gynecol. 2016, 214, 328-339. [CrossRef]

22. McGinnis, R.; Steinthorsdottir, V.; Williams, N.O.; Thorleifsson, G.; Shooter, S.; Hjartardottir, S.; Bumpstead, S.; Stefansdottir, L.; Hildyard, L.; Sigurdsson, J.K.; et al. Variants in the Fetal Genome near FLT1 Are Associated with Risk of Preeclampsia. Nat. Genet. 2017, 49, 1255-1260. [CrossRef] [PubMed]

23. Reidy, K.J.; Hjorten, R.C.; Simpson, C.L.; Rosenberg, A.Z.; Rosenblum, S.D.; Kovesdy, C.P.; Tylavsky, F.A.; Myrie, J.; Ruiz, B.L.; Haque, S.; et al. Fetal-Not Maternal-APOL1 Genotype Associated with Risk for Preeclampsia in Those with African Ancestry. Am. J. Hum. Genet. 2018, 103, 367-376. [CrossRef] [PubMed]

24. Martin, A.; Krishna, I.; Martina, B.; Samuel, A. Can the Quantity of Cell-Free Fetal DNA Predict Preeclampsia: A Systematic Review. Prenat. Diagn. 2014, 34, 685-691. [CrossRef] [PubMed]

25. Black, K.D.; Horowitz, J.A. Inflammatory Markers and Preeclampsia: A Systematic Review. Nurs. Res. 2018, 67, 242-251. [CrossRef] [PubMed]

26. Rebelo, F.; Schlussel, M.M.; Vaz, J.S.; Franco-Sena, A.B.; Pinto, T.J.P.; Bastos, F.I.; Adegboye, A.R.A.; Kac, G. C-Reactive Protein and Later Preeclampsia: Systematic Review and Meta-Analysis Taking into Account the Weight Status. J. Hypertens. 2013, 31, 16-26. [CrossRef] [PubMed]

27. Spracklen, C.N.; Smith, C.J.; Saftlas, A.F.; Robinson, J.G.; Ryckman, K.K. Maternal Hyperlipidemia and the Risk of Preeclampsia: A Meta-Analysis. Am. J. Epidemiol. 2014, 180, 346-358. [CrossRef]

28. Gallos, I.D.; Sivakumar, K.; Kilby, M.D.; Coomarasamy, A.; Thangaratinam, S.; Vatish, M. Pre-Eclampsia Is Associated with, and Preceded by, Hypertriglyceridaemia: A Meta-Analysis. BJOG 2013, 120, 1321-1332. [CrossRef]

29. Chien, P.F.; Arnott, N.; Gordon, A.; Owen, P.; Khan, K.S. How Useful Is Uterine Artery Doppler Flow Velocimetry in the Prediction of Pre-Eclampsia, Intrauterine Growth Retardation and Perinatal Death? An Overview. BJOG 2000, 107, 196-208. [CrossRef]

30. Velauthar, L.; Plana, M.N.; Kalidindi, M.; Zamora, J.; Thilaganathan, B.; Illanes, S.E.; Khan, K.S.; Aquilina, J.; Thangaratinam, S. First-Trimester Uterine Artery Doppler and Adverse Pregnancy Outcome: A Meta-Analysis Involving 55,974 Women. Ultrasound Obstet. Gynecol. 2014, 43, 500-507. [CrossRef]

31. Al-Rubaie, Z.; Askie, L.M.; Ray, J.G.; Hudson, H.M.; Lord, S.J. The Performance of Risk Prediction Models for Pre-Eclampsia Using Routinely Collected Maternal Characteristics and Comparison with Models That Include Specialised Tests and with Clinical Guideline Decision Rules: A Systematic Review. BJOG 2016, 123, 1441-1452. [CrossRef]

32. Mol, B.W.J.; Roberts, C.T.; Thangaratinam, S.; Magee, L.A.; de Groot, C.J.M.; Hofmeyr, G.J. Pre-Eclampsia. Lancet 2016, 387, 999-1011. [CrossRef] 
33. Akbari, S.; Khodadadi, B.; Ahmadi, S.A.Y.; Abbaszadeh, S.; Shahsavar, F. Association of Vitamin D Level and Vitamin D Deficiency with Risk of Preeclampsia: A Systematic Review and Updated Meta-Analysis. Taiwan. J. Obstet. Gynecol. 2018, 57, 241-247. [CrossRef] [PubMed]

34. Mirzakhani, H.; Litonjua, A.A.; McElrath, T.F.; O'Connor, G.; Lee-Parritz, A.; Iverson, R.; Macones, G.; Strunk, R.C.; Bacharier, L.B.; Zeiger, R.; et al. Early Pregnancy Vitamin D Status and Risk of Preeclampsia. J. Clin. Investig. 2016, 126, 4702-4715. [CrossRef] [PubMed]

35. Ali, A.M.; Alobaid, A.; Malhis, T.N.; Khattab, A.F. Effect of Vitamin D3 Supplementation in Pregnancy on Risk of Pre-Eclampsia-Randomized Controlled Trial. Clin. Nutr. 2019, 38, 557-563. [CrossRef] [PubMed]

36. Wei, S.-Q.; Qi, H.-P.; Luo, Z.-C.; Fraser, W.D. Maternal Vitamin D Status and Adverse Pregnancy Outcomes: A Systematic Review and Meta-Analysis. J. Matern. Fetal. Neonatal Med. 2013, 26, 889-899. [CrossRef]

37. Purswani, J.M.; Gala, P.; Dwarkanath, P.; Larkin, H.M.; Kurpad, A.; Mehta, S. The Role of Vitamin D in Pre-Eclampsia: A Systematic Review. BMC Pregnancy Childbirth 2017, 17, 231. [CrossRef]

38. Arain, N.; Mirza, W.A.; Aslam, M. Review-Vitamin D and the Prevention of Preeclampsia: A Systematic Review. Pak. J. Pharm. Sci. 2015, 28, 1015-1021. [PubMed]

39. Nassar, N.; Halligan, G.H.; Roberts, C.L.; Morris, J.M.; Ashton, A.W. Systematic Review of First-Trimester Vitamin D Normative Levels and Outcomes of Pregnancy. Am. J. Obstet. Gynecol. 2011, 205, e1-e7. [CrossRef]

40. Roth, D.E.; Leung, M.; Mesfin, E.; Qamar, H.; Watterworth, J.; Papp, E. Vitamin D Supplementation during Pregnancy: State of the Evidence from a Systematic Review of Randomised Trials. BMJ 2017, 35, j5237. [CrossRef]

41. Villar, J.; Abdel-Aleem, H.; Merialdi, M.; Mathai, M.; Ali, M.M.; Zavaleta, N.; Purwar, M.; Hofmeyr, J.; Thi Nhu Ngoc, N.; Campódonico, L.; et al. World Health Organization Randomized Trial of Calcium Supplementation among Low Calcium Intake Pregnant Women. Am. J. Obstet. Gynecol. 2006, 194, 639-649. [CrossRef]

42. Hofmeyr, G.J.; Lawrie, T.A.; Atallah, Á.N.; Torloni, M.R. Calcium Supplementation during Pregnancy for Preventing Hypertensive Disorders and Related Problems. Cochrane Database Syst. Rev. 2018, 10, CD001059. [CrossRef] [PubMed]

43. Lowe, S.A.; Bowyer, L.; Lust, K.; McMahon, L.P.; Morton, M.; North, R.A.; Paech, M.; Said, J.M. SOMANZ Guidelines for the Management of Hypertensive Disorders of Pregnancy 2014. Aust. N. Z. J. Obstet. Gynaecol. 2015, 55, e1-e29. [CrossRef] [PubMed]

44. Roberts, J.M.; August, P.A.; Bakris, G.; Barton, J.R.; Bernstein, I.M.; Druzin, M.; Gaiser, R.R.; Granger, J.R.; Jeyabalan, A.; Johnson, D.D.; et al. Hypertension in Pregnancy: Executive Summary. Obstet. Gynecol. 2013, 122, 1122-1131.

45. Tenorio, M.B.; Ferreira, R.C.; Moura, F.A.; Bueno, N.B.; Goulart, M.O.F.; Oliveira, A.C.M. Oral Antioxidant Therapy for Prevention and Treatment of Preeclampsia: Meta-Analysis of Randomized Controlled Trials. Nutr. Metab. Cardiovasc. Dis. 2018, 28, 865-876. [CrossRef] [PubMed]

46. Xu, H.; Perez-Cuevas, R.; Xiong, X.; Reyes, H.; Roy, C.; Julien, P.; Smith, G.; von Dadelszen, P.; Leduc, L.; Audibert, F; et al. An International Trial of Antioxidants in the Prevention of Preeclampsia (INTAPP). Am. J. Obstet. Gynecol. 2010, 202, 239.e1. [CrossRef] [PubMed]

47. Poston, L.; Briley, A.L.; Seed, P.T.; Kelly, F.J.; Shennan, A.H.; Vitamins in Pre-eclampsia (VIP) Trial Consortium. Vitamin C and Vitamin E in Pregnant Women at Risk for Pre-Eclampsia (VIP Trial): Randomised Placebo-Controlled Trial. Lancet 2006, 367, 1145-1154. [CrossRef]

48. Villar, J.; Ba'aqeel, H.; Piaggio, G.; Lumbiganon, P.; Miguel Belizan, J.; Farnot, U.; Al-Mazrou, Y.; Carroli, G.; Pinol, A.; Donner, A.; et al. WHO Antenatal Care Randomised Trial for the Evaluation of a New Model of Routine Antenatal Care. Lancet 2001, 357, 1551-1564. [CrossRef]

49. Chappell, L.C.; Seed, P.T.; Briley, A.L.; Kelly, F.J.; Lee, R.; Hunt, B.J.; Parmar, K.; Bewley, S.J.; Shennan, A.H.; Steer, P.J.; et al. Effect of Antioxidants on the Occurrence of Pre-Eclampsia in Women at Increased Risk: A Randomised Trial. Lancet 1999, 354, 810-816. [CrossRef]

50. Wen, S.W.; White, R.R.; Rybak, N.; Gaudet, L.M.; Robson, S.; Hague, W.; Simms-Stewart, D.; Carroli, G.; Smith, G.; Fraser, W.D.; et al. Effect of High Dose Folic Acid Supplementation in Pregnancy on Pre-Eclampsia (FACT): Double Blind, Phase III, Randomised Controlled, International, Multicentre Trial. BMJ 2018, 362, k3478. [CrossRef]

51. Saccone, G.; Sarno, L.; Roman, A.; Donadono, V.; Maruotti, G.M.; Martinelli, P. 5-Methyl-Tetrahydrofolate in Prevention of Recurrent Preeclampsia. J. Matern. Neonatal Med. 2016, 29, 916-920. [CrossRef] 
52. Dodd, J.M.; Mcleod, A.; Windrim, R.C.; Kingdom, J. Antithrombotic Therapy for Improving Maternal or Infant Health Outcomes in Women Considered at Risk of Placental Dysfunction. Cochrane Database Syst. Rev. 2013. [CrossRef]

53. Camarena Pulido, E.E.; Garcia Benavides, L.; Panduro Baron, J.G.; Pascoe Gonzalez, S.; Madrigal Saray, A.J.; Garcia Padilla, F.E.; Totsuka Sutto, S.E. Efficacy of L-Arginine for Preventing Preeclampsia in High-Risk Pregnancies: A Double-Blind, Randomized, Clinical Trial. Hypertens. Pregnancy 2016, 35, 217-225. [CrossRef] [PubMed]

54. Marrs, C.C.; Costantine, M.M. Should We Add Pravastatin to Aspirin for Preeclampsia Prevention in High-Risk Women? Clin. Obstet. Gynecol. 2017, 60, 161-168. [CrossRef] [PubMed]

55. Steyn, D.W.; Odendaal, H.J. Randomised Controlled Trial of Ketanserin and Aspirin in Prevention of Pre-Eclampsia. Lancet 1997, 350, 1267-1271. [CrossRef]

56. Teran, E.; Hernandez, I.; Nieto, B.; Tavara, R.; Ocampo, J.E.; Calle, A. Coenzyme Q10 Supplementation during Pregnancy Reduces the Risk of Pre-Eclampsia. Int. J. Gynaecol. Obstet. 2009, 105, 43-45. [CrossRef]

57. Thangaratinam, S.; Rogozinska, E.; Jolly, K.; Glinkowski, S.; Roseboom, T.; Tomlinson, J.W.; Kunz, R.; Mol, B.W.; Coomarasamy, A.; Khan, K.S. Effects of Interventions in Pregnancy on Maternal Weight and Obstetric Outcomes: Meta-Analysis of Randomised Evidence. BMJ 2012, 344, e2088. [CrossRef]

58. Allen, R.; Rogozinska, E.; Sivarajasingam, P.; Khan, K.S.; Thangaratinam, S. Effect of Diet- And Lifestyle-Based Metabolic Risk-Modifying Interventions on Preeclampsia: A Meta-Analysis. Acta Obstet. Gynecol. Scand. 2014, 93, 973-985. [CrossRef]

59. Brantsæter, A.L.; Haugen, M.; Samuelsen, S.O.; Torjusen, H.; Trogstad, L.; Alexander, J.; Magnus, P.; Meltzer, H.M. A Dietary Pattern Characterized by High Intake of Vegetables, Fruits, and Vegetable Oils Is Associated with Reduced Risk of Preeclampsia in Nulliparous Pregnant Norwegian Women. J. Nutr. 2009, 139, 1162-1168. [CrossRef]

60. Dodd, J.M.; Turnbull, D.; McPhee, A.J.; Deussen, A.R.; Grivell, R.M.; Yelland, L.N.; Crowther, C.A.; Wittert, G.; Owens, J.A.; Robinson, J.S. Antenatal Lifestyle Advice for Women Who Are Overweight or Obese: LIMIT Randomised Trial. BMJ 2014, 348, g1285. [CrossRef]

61. Magro-Malosso, E.R.; Saccone, G.; Di Tommaso, M.; Roman, A.; Berghella, V. Exercise during Pregnancy and Risk of Gestational Hypertensive Disorders: A Systematic Review and Meta-Analysis. Acta Obstet. Gynecol. Scand. 2017, 96, 921-931. [CrossRef]

62. Meher, S.; Duley, L. Exercise or Other Physical Activity for Preventing Pre-Eclampsia and Its Complications. Cochrane Database Syst. Rev. 2006, 19, CD005942. [CrossRef]

63. Conde-Agudelo, A.; Althabe, F.; Belizan, J.M.; Kafury-Goeta, A.C. Cigarette Smoking during Pregnancy and Risk of Preeclampsia: A Systematic Review. Am. J. Obstet. Gynecol. 1999, 181, 1026-1035. [CrossRef]

64. Magee, L.A.; Pels, A.; Helewa, M.; Rey, E.; von Dadelszen, P.; Audibert, F.; Bujold, E.; Côté, A.M.; Douglas, M.J.; Eastabrook, G.; et al. Diagnosis, Evaluation, and Management of the Hypertensive Disorders of Pregnancy: Executive Summary. J. Obstet. Gynaecol. Can. 2014, 36, 416-438. [CrossRef]

65. Tucker, K.L.; Taylor, K.S.; Crawford, C.; Hodgkinson, J.A.; Bankhead, C.; Carver, T.; Ewers, E.; Glogowska, M.; Greenfield, S.M.; Ingram, L.; et al. Blood Pressure Self-Monitoring in Pregnancy: Examining Feasibility in a Prospective Cohort Study. BMC Pregnancy Childbirth 2017, 17, 442. [CrossRef] [PubMed]

66. Ross-McGill, H.; Hewison, J.; Hirst, J.; Dowswell, T.; Holt, A.; Brunskill, P.; Thornton, J.G. Antenatal Home Blood Pressure Monitoring: A Pilot Randomised Controlled Trial. Br. J. Obstet. Gynaecol. 2000, 107, 217-221. [CrossRef]

67. Hinton, L.; Tucker, K.L.; Greenfield, S.M.; Hodgkinson, J.A.; Mackillop, L.; McCourt, C.; Carver, T.; Crawford, C.; Glogowska, M.; Locock, L.; et al. Blood Pressure Self-Monitoring in Pregnancy (BuMP) Feasibility Study; A Qualitative Analysis of Women's Experiences of Self-Monitoring. BMC Pregnancy Childbirth 2017, 17, 427. [CrossRef]

68. Brown, M.A. Is There a Role for Ambulatory Blood Pressure Monitoring in Pregnancy? Clin. Exp. Pharmacol. Physiol. 2014, 41, 16-21. [CrossRef]

69. Waugh, J.J.S.; Bell, S.C.; Kilby, M.D.; Blackwell, C.N.; Seed, P.; Shennan, A.H.; Halligan, A.W.F. Optimal Bedside Urinalysis for the Detection of Proteinuria in Hypertensive Pregnancy: A Study of Diagnostic Accuracy. BJOG 2005, 112, 412-417. [CrossRef] [PubMed] 
70. Menzies, J.; Magee, L.A.; MacNab, Y.C.; Ansermino, J.M.; Li, J.; Douglas, M.J.; Gruslin, A.; Kyle, P.; Lee, S.K.; Moore, M.P.; et al. Current CHS and NHBPEP Criteria for Severe Preeclampsia Do Not Uniformly Predict Adverse Maternal or Perinatal Outcomes. Hypertens. Pregnancy 2007, 26, 447-462. [CrossRef]

71. Waugh, J.; Hooper, R.; Lamb, E.; Robson, S.; Shennan, A.; Milne, F.; Price, C.; Thangaratinam, S.; Berdunov, V.; Bingham, J. Spot Protein-Creatinine Ratio and Spot Albumin-Creatinine Ratio in the Assessment of Pre-Eclampsia: A Diagnostic Accuracy Study with Decision-Analytic Model-Based Economic Evaluation and Acceptability Analysis. Health Technol. Assess. 2017, 21, 1-90. [CrossRef]

72. Kucukgoz Gulec, U.; Sucu, M.; Ozgunen, F.T.; Buyukkurt, S.; Guzel, A.B.; Paydas, S. Spot Urine Protein-to-Creatinine Ratio to Predict the Magnitude of 24-Hour Total Proteinuria in Preeclampsia of Varying Severity. J. Obstet. Gynaecol. Can. 2017, 39, 854-860. [CrossRef] [PubMed]

73. Kyle, P.M.; Fielder, J.N.; Pullar, B.; Horwood, L.J.; Moore, M.P. Comparison of Methods to Identify Significant Proteinuria in Pregnancy in the Outpatient Setting. BJOG 2008, 115, 523-527. [CrossRef] [PubMed]

74. Côté, A.M.; Brown, M.A.; Lam, E.; Von Dadelszen, P.; Firoz, T.; Liston, R.M.; Magee, L.A. Diagnostic Accuracy of Urinary Spot Protein:Creatinine Ratio for Proteinuria in Hypertensive Pregnant Women: Systematic Review. BMJ 2008, 336, 1003-1006. [CrossRef] [PubMed]

75. Price, C.P.; Newall, R.G.; Boyd, J.C. Use of Protein: Creatinine Ratio Measurements on Random Urine Samples for Prediction of Significant Proteinuria: A Systematic Review. Clin. Chem. 2005, 51, 1577-1586. [CrossRef] [PubMed]

76. Karumanchi, S.A.; Epstein, F.H. Placental Ischemia and Soluble Fms-like Tyrosine Kinase 1: Cause or Consequence of Preeclampsia? Kidney Int. 2007, 71, 959-961. [CrossRef] [PubMed]

77. Levine, R.J.; Lam, C.; Qian, C.; Yu, K.F.; Maynard, S.E.; Sachs, B.P.; Sibai, B.M.; Epstein, F.H.; Romero, R.; Thadhani, R.; et al. Soluble Endoglin and Other Circulating Antiangiogenic Factors in Preeclampsia. N. Engl. J. Med. 2006, 355, 992-1005. [CrossRef] [PubMed]

78. Chappell, L.C.; Duckworth, S.; Seed, P.T.; Griffin, M.; Myers, J.; Mackillop, L.; Simpson, N.; Waugh, J.; Anumba, D.; Kenny, L.C.; et al. Diagnostic Accuracy of Placental Growth Factor in Women with Suspected Preeclampsia: A Prospective Multicenter Study. Circulation 2013, 128, 2121-2131. [CrossRef] [PubMed]

79. Duhig, K.E.; Myers, J.; Seed, P.T.; Sparkes, J.; Lowe, J.; Hunter, R.M.; Shennan, A.H.; Chappell, L.C.; Bahl, R.; Bambridge, G.; et al. Placental Growth Factor Testing to Assess Women with Suspected Pre-Eclampsia: A Multicentre, Pragmatic, Stepped-Wedge Cluster-Randomised Controlled Trial. Lancet 2019, 393, 1807-1818. [CrossRef]

80. Zeisler, H.; Llurba, E.; Chantraine, F.; Vatish, M.; Staff, A.C.; Sennström, M.; Olovsson, M.; Brennecke, S.P.; Stepan, H.; Allegranza, D.; et al. Predictive Value of the SFlt-1:PlGF Ratio in Women with Suspected Preeclampsia. N. Engl. J. Med. 2016, 374, 13-22. [CrossRef]

81. Steegers, E.A.P.; von Dadelszen, P.; Duvekot, J.J.; Pijnenborg, R. Pre-Eclampsia. Lancet 2010, 376, $631-644$. [CrossRef]

82. Phipps, E.A.; Thadhani, R.; Benzing, T.; Karumanchi, S.A. Pre-Eclampsia: Pathogenesis, Novel Diagnostics and Therapies. Nat. Rev. Nephrol. 2019, 15, 275-289. [CrossRef] [PubMed]

83. Rana, S.; Lemoine, E.; Granger, J.; Karumanchi, S.A. Preeclampsia: Pathophysiology, Challenges, and Perspectives. Circ. Res. 2019, 124, 1094-1112. [CrossRef] [PubMed]

84. ACOG Practice Bulletin No. 202: Gestational Hypertension and Preeclampsia. Obstet. Gynecol. 2019, 133, e1-e25.

85. Grant, A.; Valentin, L.; Elbourne, D.; Alexander, S. Routine Formal Fetal Movement Counting and Risk of Antepartum Late Death in Normally Formed Singletons. Lancet 1989, 334, 345-349. [CrossRef]

86. Lalor, J.G.; Fawole, B.; Alfirevic, Z.; Devane, D. Biophysical Profile for Fetal Assessment in High Risk Pregnancies. Cochrane Database Syst. Rev. 2008, 23, CD000038. [CrossRef]

87. Grivell, R.M.; Alfirevic, Z.; Gyte, G.M.L.; Devane, D. Antenatal Cardiotocography for Fetal Assessment. Cochrane Database Syst. Rev. 2015. [CrossRef]

88. Nabhan, A.F.; Abdelmoula, Y.A. Amniotic Fluid Index versus Single Deepest Vertical Pocket as a Screening Test for Preventing Adverse Pregnancy Outcome. Cochrane Database Syst. Rev. 2008. [CrossRef]

89. Williams, K.P.; Farquharson, D.F.; Bebbington, M.; Dansereau, J.; Galerneau, F.; Wilson, R.D.; Shaw, D.; Kent, N. Screening for Fetal Well-Being in a High-Risk Pregnant Population Comparing the Nonstress Test with Umbilical Artery Doppler Velocimetry: A Randomized Controlled Clinical Trial. Am. J. Obstet. Gynecol. 2003, 188, 1366-1371. [CrossRef] 
90. Alfirevic, Z.; Stampalija, T.; Dowswell, T. Fetal and Umbilical Doppler Ultrasound in High-Risk Pregnancies. Cochrane Database Syst. Rev. 2017. [CrossRef]

91. Alfirevic, Z.; Neilson, J.P. Doppler Ultrasonography in High-Risk Pregnancies: Systematic Review with Meta-Analysis. Am. J. Obstet. Gynecol. 1995, 172, 1379-1387. [CrossRef]

92. Karsdorp, V.H.M.; van Vugt, J.M.G.; van Geijn, H.P.; Kostense, P.J.; Arduim, D.; Montenegro, N.; Todros, T. Clinical Significance of Absent or Reversed End Diastolic Velocity Waveforms in Umbilical Artery. Lancet 1994, 344, 1664-1668. [CrossRef]

93. Arduini, D.; Rizzo, G.; Romanini, C. The Development of Abnormal Heart Rate Patterns after Absent End-Diastolic Velocity in Umbilical Artery: Analysis of Risk Factors. Am. J. Obstet. Gynecol. 2013, 168, 43-50. [CrossRef]

94. Westergaard, H.B.; Langhoff-Roos, J.; Lingman, G.; Marsál, K.; Kreiner, S. A Critical Appraisal of the Use of Umbilical Artery Doppler Ultrasound in High-Risk Pregnancies: Use of Meta-Analyses in Evidence-Based Obstetrics. Ultrasound Obstet. Gynecol. 2001, 17, 466-476. [CrossRef]

95. Yagel, S.; Kivilevitch, Z.; Cohen, S.M.; Valsky, D.V.; Messing, B.; Shen, O.; Achiron, R. The Fetal Venous System, Part II: Ultrasound Evaluation of the Fetus with Congenital Venous System Malformation or Developing Circulatory Compromise. Ultrasound Obstet. Gynecol. 2010, 36, 93-111. [CrossRef] [PubMed]

96. Baschat, A.A.; Cosmi, E.; Bilardo, C.M.; Wolf, H.; Berg, C.; Rigano, S.; Germer, U.; Moyano, D.; Turan, S.; Hartung, J.; et al. Predictors of Neonatal Outcome in Early-Onset Placental Dysfunction. Obstet. Gynecol. 2007, 109, 253-261. [CrossRef]

97. Harrington, K.; Thompson, M.O.; Carpenter, R.G.; Nguyen, M.; Campbell, S. Doppler Fetal Circulation in Pregnancies Complicated by Pre-Eclampsia or Delivery of a Small for Gestational Age Baby: 2. Longitudinal Analysis. BJOG An. Int. J. Obstet. Gynaecol. 1999, 106, 453-466. [CrossRef] [PubMed]

98. Özeren, M.; Dinç, H.; Ekmen, Ü.; Senekayli, C.; Aydemir, V. Umbilical and Middle Cerebral Artery Doppler Indices in Patients with Preeclampsia. Eur. J. Obstet. Gynecol. Reprod. Biol. 1999, 82, 11-16. [CrossRef]

99. Eser, A.; Zulfikaroglu, E.; Eserdag, S.; Kilic, S.; Danisman, N. Predictive Value of Middle Cerebral Artery to Uterine Artery Pulsatility Index Ratio in Preeclampsia. Arch. Gynecol. Obstet. 2011, 284, 307-311. [CrossRef]

100. Simanaviciute, D.; Gudmundsson, S. Fetal Middle Cerebral to Uterine Artery Pulsatility Index Ratios in Normal and Pre-Eclamptic Pregnancies. Ultrasound Obstet. Gynecol. 2006, 28, 794-801. [CrossRef]

101. Makhseed, M.; Jirous, J.; Ahmed, M.A.; Viswanathan, D.L. Middle Cerebral Artery to Umbilical Artery Resistance Index Ratio in the Prediction of Neonatal Outcome. Int. J. Gynecol. Obstet. 2000, 71, 119-125. [CrossRef]

102. Ebrashy, A.; Azmy, O.; Ibrahim, M.; Waly, M.; Edris, A. Middle Cerebral/Umbilical Artery Resistance Index Ratio as Sensitive Parameter for Fetal Well-Being and Neonatal Outcome in Patients with Preeclampsia: Case-Control Study. Croat. Med. J. 2005, 46, 821-825. [PubMed]

103. Campbell, S.; Griffin, D.R.; Pearce, J.M.; Diaz-Recasens, J.; Cohen-Overbeek, T.E.; Willson, K.; Teague, M.J. New Doppler Technique for Assessing Uteroplacental Blood Flow. Lancet 1983, 321, 675-677. [CrossRef]

104. Thangaratinam, S.; Ismail, K.M.K.; Sharp, S.; Coomarasamy, A.; Khan, K.S. Accuracy of Serum Uric Acid in Predicting Complications of Pre-Eclampsia: A Systematic Review. BJOG 2006, 169, 369-378. [CrossRef] [PubMed]

105. Thangaratinam, S.; Coomarasamy, A.; O’Mahony, F.; Sharp, S.; Zamora, J.; Khan, K.S.; Ismail, K.M.K. Estimation of Proteinuria as a Predictor of Complications of Pre-Eclampsia: A Systematic Review. BMC Med. 2009, 7, 10. [CrossRef]

106. Thangaratinam, S.; Koopmans, C.M.; Iyengar, S.; Zamora, J.; Ismail, K.M.K.; Mol, B.W.J.; Khan, K.S.; TIPPS (Tests in Prediction of Preeclampsia's Severity) Review Group. Accuracy of Liver Function Tests for Predicting Adverse Maternal and Fetal Outcomes in Women with Preeclampsia: A Systematic Review. Acta Obstet. Gynecol. Scand. 2011, 90, 574-585. [CrossRef] [PubMed]

107. Tsikas, D.; Bollenbach, A.; Savvidou, M.D. Inverse Correlation between Maternal Plasma Asymmetric Dimethylarginine (ADMA) and Birthweight Percentile in Women with Impaired Placental Perfusion: Circulating ADMA as an NO-Independent Indicator of Fetal Growth Restriction? Amino Acids 2018, 50, 341-351. [CrossRef]

108. Ali, Z.; Bokhari, F.A.; Zaki, S.; Zargham, U.; Tauseef, A.; Khakan, S. Correlation of CRP Levels in Third Trimester with Fetal Birth Weight in Preeclamptic and Normotensive Pregnant Women. J. Coll. Physicians Surg. Pak. 2015, 25, 111-114. [PubMed] 
109. Goldenberg, R.L.; Culhane, J.F.; Iams, J.D.; Romero, R. Epidemiology and Causes of Preterm Birth. Lancet 2008, 371, 75-84. [CrossRef]

110. National Guideline Alliance (UK). Preterm Labour and Birth (NG25). 2015. Available online: https: //www.nice.org.uk/guidance/ng25 (accessed on 3 October 2019).

111. Roberts, D.; Brown, J.; Medley, N.; Dalziel, S.R. Antenatal Corticosteroids for Accelerating Fetal Lung Maturation for Women at Risk of Preterm Birth. Cochrane Database Syst. Rev. 2017, 3, CD004454.

112. Brownfoot, F.C.; Gagliardi, D.I.; Bain, E.; Middleton, P.; Crowther, C.A. Different Corticosteroids and Regimens for Accelerating Fetal Lung Maturation for Women at Risk of Preterm Birth. Cochrane Database Syst. Rev. 2013. [CrossRef]

113. Kashanian, M.; Eshraghi, N.; Sheikhansari, N.; Bordbar, A.; Khatami, E. Comparison between Two Doses of Betamethasone Administration with 12 Hours vs. 24 Hours Intervals on Prevention of Respiratory Distress Syndrome: A Randomised Trial. J. Obstet. Gynaecol. 2018, 38, 770-776. [CrossRef] [PubMed]

114. Porto, A.M.F.; Coutinho, I.C.; Correia, J.B.; Amorim, M.M.R. Effectiveness of Antenatal Corticosteroids in Reducing Respiratory Disorders in Late Preterm Infants: Randomised Clinical Trial. BMJ 2011, 342, d1696. [CrossRef] [PubMed]

115. Saccone, G.; Berghella, V. Antenatal Corticosteroids for Maturity of Term or near Term Fetuses: Systematic Review and Meta-Analysis of Randomized Controlled Trials. BMJ 2016, 355, i5044. [CrossRef] [PubMed]

116. Kelly, B.A.; Lewandowski, A.J.; Worton, S.A.; Davis, E.F.; Lazdam, M.; Francis, J.; Neubauer, S.; Lucas, A.; Singhal, A.; Leeson, P. Antenatal Glucocorticoid Exposure and Long-Term Alterations in Aortic Function and Glucose Metabolism. Pediatrics 2012, 129, e1282-e1290. [CrossRef] [PubMed]

117. Crowther, C.A.; Haslam, R.R.; Hiller, J.E.; Doyle, L.W.; Robinson, J.S. Neonatal Respiratory Distress Syndrome after Repeat Exposure to Antenatal Corticosteroids: A Randomised Controlled Trial. Lancet 2006, 367, 1913-1919. [CrossRef]

118. Murphy, K.E.; Hannah, M.E.; Willan, A.R.; Hewson, S.A.; Ohlsson, A.; Kelly, E.N.; Matthews, S.G.; Saigal, S.; Asztalos, E.; Ross, S.; et al. Multiple Courses of Antenatal Corticosteroids for Preterm Birth (MACS): A Randomised Controlled Trial. Lancet 2008, 372, 2143-2151. [CrossRef]

119. Atarod, Z.; Taghipour, M.; Roohanizadeh, H.; Fadavi, S.; Taghavipour, M. Effects of Single Course and Multicourse Betamethasone Prior to Birth in the Prognosis of the Preterm Neonates. J. Res. Med. Sci. 2014, 19, 715-719. [PubMed]

120. Crowther, C.A.; Doyle, L.W.; Haslam, R.R.; Hiller, J.E.; Harding, J.E.; Robinson, J.S. Outcomes at 2 Years of Age after Repeat Doses of Antenatal Corticosteroids. N. Engl. J. Med. 2007, 357, 1179-1189. [CrossRef]

121. Asztalos, E.V.; Murphy, K.E.; Willan, A.R.; Matthews, S.G.; Ohlsson, A.; Saigal, S.; Armson, B.A.; Kelly, E.N.; Delisle, M.F.; Gafni, A.; et al. Multiple Courses of Antenatal Corticosteroids for Preterm Birth Study Outcomes in Children at 5 Years of Age (MACS-5). JAMA Pediatr. 2013, 167, 1102-1110.

122. Asztalos, E.V.; Murphy, K.E.; Hannah, M.E.; Willan, A.R.; Matthews, S.G.; Ohlsson, A.; Kelly, E.N.; Saigal, S.; Ross, S.; Delisle, M.-F.; et al. Multiple Courses of Antenatal Corticosteroids for Preterm Birth Study: 2-Year Outcomes. Pediatrics 2010, 126, E1045-E1055.

123. Doyle, L.W.; Crowther, C.A.; Middleton, P.; Marret, S.; Rouse, D. Magnesium Sulphate for Women at Risk of Preterm Birth for Neuroprotection of the Fetus. Cochrane Database Syst. Rev. 2009. [CrossRef]

124. Duley, L. Do Women with Pre-Eclampsia, and Their Babies, Benefit from Magnesium Sulphate? The Magpie Trial: A Randomised Placebo-Controlled Trial. Lancet 2002, 359, 1877-1890.

125. Duley, L.; Farrell, B.; Armstrong, N.; Spark, P.; Roberts, B.; Smyth, R.; Tivnan, M.; Laws, A.; Corfield, N.; Salter, A.; et al. The Magpie Trial: A Randomised Trial Comparing Magnesium Sulphate with Placebo for Pre-Eclampsia. Outcome for Children at 18 Months. BJOG 2007, 114, 289-299.

126. Bombrys, A.E.; Barton, J.R.; Nowacki, E.A.; Habli, M.; Pinder, L.; How, H.; Sibai, B.M. Expectant Management of Severe Preeclampsia at Less than 27 Weeks' Gestation: Maternal and Perinatal Outcomes According to Gestational Age by Weeks at Onset of Expectant Management. Am. J. Obstet. Gynecol. 2008, 199, e1-e6. [CrossRef]

127. Budden, A.; Wilkinson, L.; Buksh, M.J.; McCowan, L. Pregnancy Outcome in Women Presenting with Pre-Eclampsia at Less than 25 Weeks Gestation. Aust. N. Z. J. Obstet. Gynaecol. 2006, 46, 407-412. [CrossRef] [PubMed] 
128. Churchill, D.; Duley, L.; Thornton, J.G.; Moussa, M.; Ali, H.S.M.; Walker, K.F. Interventionist versus Expectant Care for Severe Pre-Eclampsia between 24 and 34 Weeks' Gestation. Cochrane Database Syst. Rev. 2018. [CrossRef]

129. Bernardes, T.P.; Zwertbroek, E.F.; Broekhuijsen, K.; Koopmans, C.; Boers, K.; Owens, M.; Thornton, J.; van Pampus, M.G.; Scherjon, S.A.; Wallace, K.; et al. Delivery or Expectant Management for Prevention of Adverse Maternal and Neonatal Outcomes in Hypertensive Disorders of Pregnancy: An Individual Participant Data Meta-Analysis. Ultrasound Obstet. Gynecol. 2019, 53, 443-453. [CrossRef]

130. Chappell, L.C.; Green, M.; Marlow, N.; Sandall, J.; Hunter, R.; Robson, S.; Bowler, U.; Chiocchia, V.; Hardy, P.; Juszczak, E.; et al. Planned Delivery or Expectant Management for Late Preterm Pre-Eclampsia: Study Protocol for a Randomised Controlled Trial (PHOENIX Trial). Trials 2019, 20, 85. [CrossRef]

131. Koopmans, C.M.; Bijlenga, D.; Groen, H.; Vijgen, S.M.C.; Aarnoudse, J.G.; Bekedam, D.J.; van den Berg, P.P.; de Boer, K.; Burggraaff, J.M.; Bloemenkamp, K.W.M.; et al. Induction of Labour versus Expectant Monitoring for Gestational Hypertension or Mild Pre-Eclampsia after 36 Weeks' Gestation (HYPITAT): A Multicentre, Open-Label Randomised Controlled Trial. Lancet 2009, 374, 979-988. [CrossRef]

132. Thornton, J.G.; Hornbuckle, J.; Vail, A.; Spiegelhalter, D.J.; Levene, M. GRIT study group. Infant Wellbeing at 2 Years of Age in the Growth Restriction Intervention Trial (GRIT): Multicentred Randomised Controlled Trial. Lancet 2004, 364, 513-520.

133. Van Bulck, B.; Kalakoutis, G.M.; Sak, P.; Schneider, K.T.M.; Major, T.; Karpathios, S.E.; Todros, T.; Arduini, D.; Tranquilli, A.; Tenore, A.C.; et al. A Randomised Trial of Timed Delivery for the Compromised Preterm Fetus: Short Term Outcomes and Bayesian Interpretation. BJOG 2003, 110, 27-32.

134. Bilardo, C.M.; Wolf, H.; Stigter, R.H.; Ville, Y.; Baez, E.; Visser, G.H.A.; Hecher, K. Relationship between Monitoring Parameters and Perinatal Outcome in Severe, Early Intrauterine Growth Restriction. Ultrasound Obstet. Gynecol. 2004, 23, 119-125. [CrossRef] [PubMed]

135. Lees, C.C.; Marlow, N.; Van Wassenaer-Leemhuis, A.; Arabin, B.; Bilardo, C.M.; Brezinka, C.; Calvert, S.; Derks, J.B.; Diemert, A.; Duvekot, J.J.; et al. 2 Year Neurodevelopmental and Intermediate Perinatal Outcomes in Infants with Very Preterm Fetal Growth Restriction (TRUFFLE): A Randomised Trial. Lancet 2015, 385, 2162-2172. [CrossRef]

136. Sameshima, H.; Kodama, Y.; Ikenoue, T.; Kajiwara, Y. Antithrombin Improves Fetal Condition in Women with Severe Pre-Eclampsia before 32 Weeks of Gestation; a Randomized, Double-Blind, Placebo-Controlled Trial. J. Obstet. Gynaecol. Res. 2008, 34, 34-39. [CrossRef] [PubMed]

137. Herraiz, S.; Pellicer, B.; Serra, V.; Cauli, O.; Cortijo, J.; Felipo, V.; Pellicer, A. Sildenafil Citrate Improves Perinatal Outcome in Fetuses from Pre-Eclamptic Rats. BJOG 2012, 119, 1394-1402. [CrossRef] [PubMed]

138. Costantine, M.M.; Cleary, K. Pravastatin for the Prevention of Preeclampsia in High-Risk Pregnant Women. Obstet. Gynecol. 2013, 121, 349-353. [CrossRef]

139. Brownfoot, F.C.; Tong, S.; Hannan, N.J.; Binder, N.K.; Walker, S.P.; Cannon, P.; Hastie, R.; Onda, K.; Kaitu'U-Lino, T.J. Effects of Pravastatin on Human Placenta, Endothelium, and Women with Severe Preeclampsia. Hypertension 2015, 66, 687-697. [CrossRef] [PubMed]

140. Costantine, M.M.; Cleary, K.; Hebert, M.F.; Ahmed, M.S.; Brown, L.M.; Ren, Z.; Easterling, T.R.; Haas, D.M.; Haneline, L.S.; Caritis, S.N.; et al. Safety and Pharmacokinetics of Pravastatin Used for the Prevention of Preeclampsia in High-Risk Pregnant Women: A Pilot Randomized Controlled Trial. Am. J. Obstet. Gynecol. 2016, 214, e17. [CrossRef]

141. Brownfoot, F.C.; Hastie, R.; Hannan, N.J.; Cannon, P.; Tuohey, L.; Parry, L.J.; Senadheera, S.; Illanes, S.E.; Kaitu'U-Lino, T.J.; Tong, S. Metformin as a Prevention and Treatment for Preeclampsia: Effects on Soluble Fms-like Tyrosine Kinase 1 and Soluble Endoglin Secretion and Endothelial Dysfunction. Am. J. Obstet. Gynecol. 2016, 214, e15. [CrossRef]

142. Thadhani, R.; Kisner, T.; Hagmann, H.; Bossung, V.; Noack, S.; Schaarschmidt, W.; Jank, A.; Kribs, A.; Cornely, O.A.; Kreyssig, C.; et al. Pilot Study of Extracorporeal Removal of Soluble Fms-like Tyrosine Kinase 1 in Preeclampsia. Circulation 2011, 124, 940-950. [CrossRef]

143. Thadhani, R.; Hagmann, H.; Schaarschmidt, W.; Roth, B.; Cingoez, T.; Karumanchi, S.A.; Wenger, J.; Lucchesi, K.J.; Tamez, H.; Lindner, T.; et al. Removal of Soluble Fms-like Tyrosine Kinase-1 by Dextran Sulfate Apheresis in Preeclampsia. J. Am. Soc. Nephrol. 2016, 27, 903-913. [CrossRef] [PubMed]

144. Perry, H.; Khalil, A.; Thilaganathan, B. Preeclampsia and the Cardiovascular System: An Update. Trends Cardiovasc. Med. 2018, 28, 505-513. [CrossRef] [PubMed] 
145. Thilaganathan, B.; Kalafat, E. Cardiovascular System in Preeclampsia and Beyond. Hypertension 2019, 73, 522-531. [CrossRef] [PubMed]

146. Ahmed, R.; Dunford, J.; Mehran, R.; Robson, S.; Kunadian, V. Pre-Eclampsia and Future Cardiovascular Risk among Women: A Review. J. Am. Coll. Cardiol. 2014, 63, 1815-1822. [CrossRef] [PubMed]

147. Davis, E.F.; Lewandowski, A.J.; Aye, C.; Williamson, W.; Boardman, H.; Huang, R.C.; Mori, T.A.; Newnham, J.; Beilin, L.J.; Leeson, P. Clinical Cardiovascular Risk during Young Adulthood in Offspring of Hypertensive Pregnancies: Insights from a 20-Year Prospective Follow-up Birth Cohort. BMJ Open 2015, 5, e008136. [CrossRef] [PubMed]

148. Ferreira, I.; Peeters, L.L.; Stehouwer, C.D.A. Preeclampsia and Increased Blood Pressure in the Offspring: Meta-Analysis and Critical Review of the Evidence. J. Hypertens. 2009, 27, 1955-1959. [CrossRef] [PubMed]

149. Kajantie, E.; Eriksson, J.G.; Osmond, C.; Thornburg, K.; Barker, D.J.P. Pre-Eclampsia Is Associated With Increased Risk of Stroke in the Adult Offspring. Stroke 2009, 40, 1176-1180. [CrossRef] [PubMed]

150. Lazdam, M.; De La Horra, A.; Diesch, J.; Kenworthy, Y.; Davis, E.; Lewandowski, A.J.; Szmigielski, C.; Shore, A.; MacKillop, L.; Kharbanda, R.; et al. Unique Blood Pressure Characteristics in Mother and Offspring after Early Onset Preeclampsia. Hypertension 2012, 60, 1338-1345. [CrossRef] [PubMed]

151. Lazdam, M.; De La Horra, A.; Pitcher, A.; Mannie, Z.; Diesch, J.; Trevitt, C.; Kylintireas, I.; Contractor, H.; Singhal, A.; Lucas, A.; et al. Elevated Blood Pressure in Offspring Born Premature to Hypertensive Pregnancy: Is Endothelial Dysfunction the Underlying Vascular Mechanism? Hypertension 2010, 56, 159-165. [CrossRef]

152. Alsnes, I.V.; Vatten, L.J.; Fraser, A.; Bjørngaard, J.H.; Rich-Edwards, J.; Romundstad, P.R.; Åsvold, B.O. Hypertension in Pregnancy and Offspring Cardiovascular Risk in Young Adulthood: Prospective and Sibling Studies in the HUNT Study (Nord-Trøndelag Health Study) in Norway. Hypertension 2017, 69, 591-598. [CrossRef]

153. Yu, G.Z.; Leeson, P. Hypertension: Hypertension in Pregnancy: A Risk Factor for the Whole Family? Nat. Rev. Nephrol. 2017, 13, 326-327. [CrossRef] [PubMed]

154. Davis, E.F.; Newton, L.; Lewandowski, A.J.; Lazdam, M.; Kelly, B.A.; Kyriakou, T.; Leeson, P. Pre-Eclampsia and Offspring Cardiovascular Health: Mechanistic Insights from Experimental Studies. Clin. Sci. 2012, 123, 53-72. [CrossRef] [PubMed]

155. Akcakus, M.; Altunay, L.; Yikilmaz, A.; Yazici, C.; Koklu, E. The Relationship between Abdominal Aortic Intima-Media Thickness and Lipid Profile in Neonates Born to Mothers with Preeclampsia. J. Pediatr. Endocrinol. Metab. 2010, 23, 1143-1149. [CrossRef]

156. Kvehaugen, A.S.; Dechend, R.; Ramstad, H.B.; Troisi, R.; Fugelseth, D.; Staff, A.C. Endothelial Function and Circulating Biomarkers Are Disturbed in Women and Children after Preeclampsia. Hypertension 2011, 58, 63-69. [CrossRef] [PubMed]

157. Jayet, P.Y.; Rimoldi, S.F.; Stuber, T.; Salinas Salmòn, C.; Hutter, D.; Rexhaj, E.; Thalmann, S.; Schwab, M.; Turini, P.; Sartori-Cucchia, C.; et al. Pulmonary and Systemic Vascular Dysfunction in Young Offspring of Mothers with Preeclampsia. Circulation 2010, 122, 488-494. [CrossRef]

158. Lawlor, D.A.; MacDonald-Wallis, C.; Fraser, A.; Nelson, S.M.; Hingorani, A.; Davey Smith, G.; Sattar, N.; Deanfield, J. Cardiovascular Biomarkers and Vascular Function during Childhood in the Offspring of Mothers with Hypertensive Disorders of Pregnancy: Findings from the Avon Longitudinal Study of Parents and Children. Eur. Heart J. 2012, 33, 335-345. [CrossRef]

159. Yu, G.Z.; Aye, C.Y.L.; Lewandowski, A.J.; Davis, E.F.; Khoo, C.P.; Newton, L.; Yang, C.T.; Al Haj Zen, A.; Simpson, L.J.; O’Brien, K.; et al. Association of Maternal Antiangiogenic Profile at Birth with Early Postnatal Loss of Microvascular Density in Offspring of Hypertensive Pregnancies. Hypertension 2016, 68, 749-759. [CrossRef]

160. Yu, G.Z.; Reilly, S.; Lewandowski, A.J.; Aye, C.Y.L.; Simpson, L.J.; Newton, L.D.; Davis, E.F.; Zhu, S.J.; Fox, W.R.; Goel, A.; et al. Neonatal MicroRNA Profile Determines Endothelial Function in Offspring of Hypertensive Pregnancies. Hypertension 2018, 72, 937-945. [CrossRef]

161. Timpka, S.; Macdonald-Wallis, C.; Hughes, A.D.; Chaturvedi, N.; Franks, P.W.; Lawlor, D.A.; Fraser, A. Hypertensive Disorders of Pregnancy and Offspring Cardiac Structure and Function in Adolescence. J. Am. Heart Assoc. 2016, 5, e003906. [CrossRef] 
162. Lewandowski, A.J.; Augustine, D.; Lamata, P.; Davis, E.F.; Lazdam, M.; Francis, J.; McCormick, K.; Wilkinson, A.R.; Singhal, A.; Lucas, A.; et al. Preterm Heart in Adult Life: Cardiovascular Magnetic Resonance Reveals Distinct Differences in Left Ventricular Mass, Geometry, and Function. Circulation 2013, 127, 197-206. [CrossRef]

163. Aye, C.Y.L.; Lewandowski, A.J.; Oster, J.; Upton, R.; Davis, E.; Kenworthy, Y.; Boardman, H.; Yu, G.Z.; Siepmann, T.; Adwani, S.; et al. Neonatal Autonomic Function after Pregnancy Complications and Early Cardiovascular Development. Pediatr. Res. 2018, 84, 85-91. [CrossRef] [PubMed]

164. Aye, C.Y.L.; Lewandowski, A.J.; Lamata, P.; Upton, R.; Davis, E.; Ohuma, E.O.; Kenworthy, Y.; Boardman, H.; Wopperer, S.; Packham, A.; et al. Disproportionate Cardiac Hypertrophy during Early Postnatal Development in Infants Born Preterm. Pediatr. Res. 2017, 82, 36-46. [CrossRef] [PubMed]

165. Nathan, H.L.; Seed, P.T.; Hezelgrave, N.L.; De Greeff, A.; Lawley, E.; Anthony, J.; Hall, D.R.; Steyn, W.; Chappell, L.C.; Shennan, A.H. Early Warning System Hypertension Thresholds to Predict Adverse Outcomes in Pre-Eclampsia: A Prospective Cohort Study. Pregnancy Hypertens. 2018, 12, 183-188. [CrossRef] [PubMed]

166. Nathan, H.L.; Duhig, K.; Vousden, N.; Lawley, E.; Seed, P.T.; Sandall, J.; Bellad, M.B.; Brown, A.C.; Chappell, L.C.; Goudar, S.S.; et al. Evaluation of a Novel Device for the Management of High Blood Pressure and Shock in Pregnancy in Low-Resource Settings: Study Protocol for a Stepped-Wedge Cluster-Randomised Controlled Trial (CRADLE-3 Trial). Trials 2018, 19, 206. [CrossRef] [PubMed]

(C) 2019 by the authors. Licensee MDPI, Basel, Switzerland. This article is an open access article distributed under the terms and conditions of the Creative Commons Attribution (CC BY) license (http://creativecommons.org/licenses/by/4.0/). 